
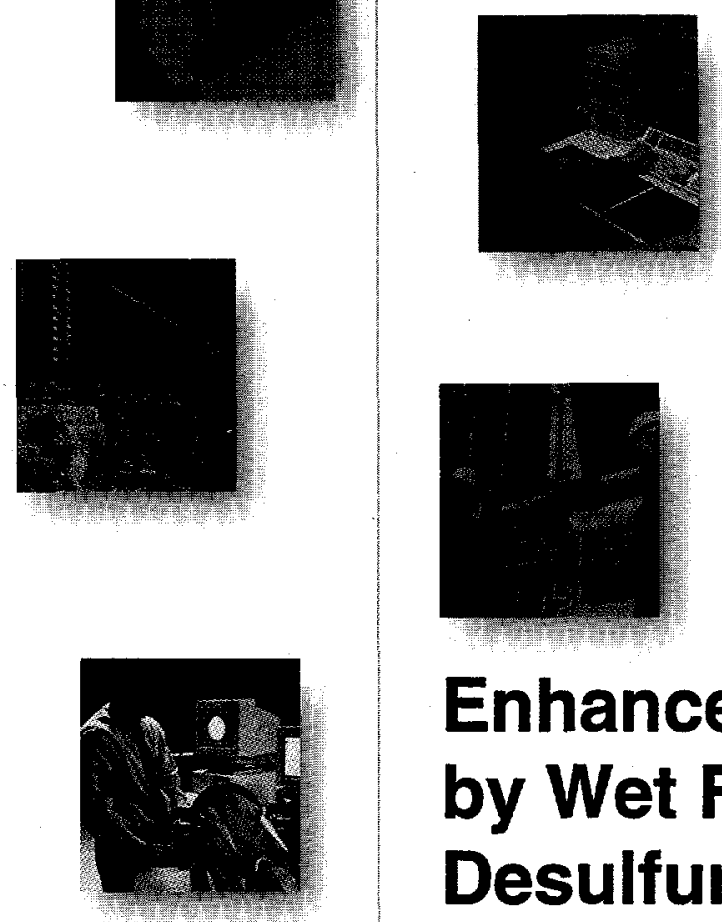

Enhanced Control of Mercury by Wet Flue Gas Desulfurization Systems Site 1 Results

Submitted to:

U.S. Department of Energy Federal Energy Technology Center Cochran Mill Road Pittsburgh, Pennsylvania 15236 


\section{Enhanced Control of Mercury by Wet Flue Gas Desulfurization Systems - Site 1 Results}

For:

U.S. Department of Energy

Federal Energy Technology Center Cochran Mill Road

Pittsburgh, Pennsylvania 15236
TEGENVE

NOV 092000

C.STI

May 1999 


\section{DISCLAIMER}

This report was prepared as an account of work sponsored by an agency of the United States Government. Neither the United States Government nor any agency thereof, nor any of their employees, make any warranty, express or implied, or assumes any legal liability or responsibility for the accuracy, completeness, or usefulness of any information, apparatus, product, or process disclosed, or represents that its use would not infringe privately owned rights. Reference herein to any specific commercial product, process, or service by trade name, trademark, manufacturer, or otherwise does not necessarily constitute or imply its endorsement, recommendation, or favoring by the United States Government or any agency thereof. The views and opinions of authors expressed herein do not necessarily state or reflect those of the United States Government or any agency thereof. 


\section{DISCLAIMER}

Portions of this document may be illegible in electronic image products. Images are produced from the best available original document. 
TABLE OF CONTENTS

Page

INTRODUCTION

PHASE II TECHNICAL APPROACH............................................................................................... 1

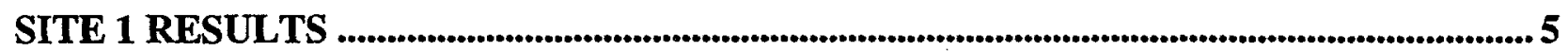

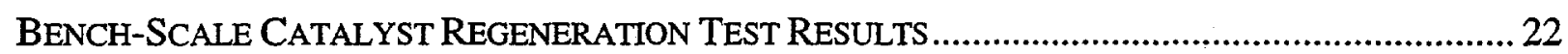

SAND

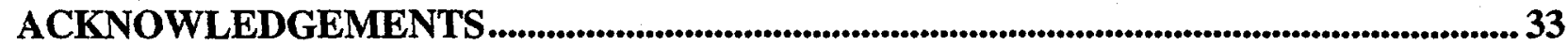

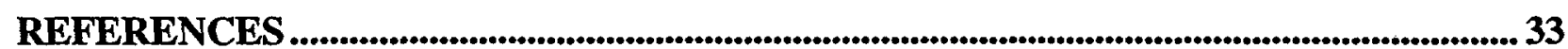

APPENDIX A: DETAILED MEASUREMENT RESULTS FROM THE SECOND

LONG-TERM TEST PERIOD A-1 


\section{LIST OF FIGURES}

1. Catalyst Field TeSt UNIT AND Mercury ANALYZER ...................................................... 3

2. BENCH-SCALE, FIXED BED MERCURY OXIDATION TEST UNIT ......................................... 6

3. SITE 1 CATALYST ACTIVITY RESULTS FOR FGD CARBON................................................. 16

4. SITE 1 ACTIVTTY RESULTS FOR VARIOUS CATALYST MATERIALS ........................................ 17

5. Total MERCuRy CONCENTRATION VS. FGD INLET $\mathrm{SO}_{2}$ CONCENTRATION AT SITE 1 ............... 21

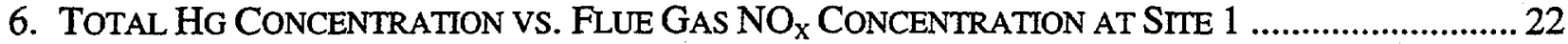

7. Percent Elemental Mercury Oxidation vs. FGD Inlet $\mathrm{SO}_{2}$ Concentration................ 23

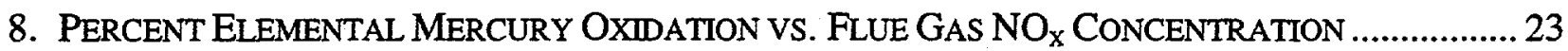

9. COMPARISON OF ELEMENTAL MERCURY OXIDATION BETWEEN REAGENTS AND RECOVERED FIELD SAMPLES AT SITE 1 CONDITIONS AND 300 $0^{\circ}$ F................................................... 28

10. RESULTS OF ACID LEACHING TESTS ON CATALYST SAMPLES FROM THE FIRST AND SECOND

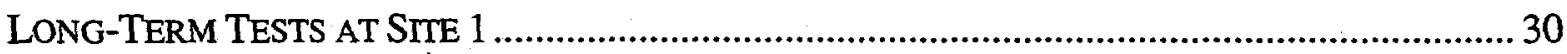

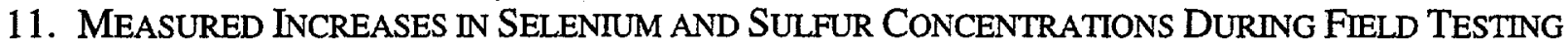
AT SITE 1 (SAMPLES FROM SECOND LONG-TERM TEST).

12. PERCENT OF ADSORBED MATERLAL THAT DESORBED DURING REGENERATION WITH $\mathrm{CO}_{2}$ AT $700^{\circ} \mathrm{F}$ (SAMPLES FROM SECOND LONG-TERM TEST)

\section{LIST OF TABLES}

1. Simulated Flue Gas Conditions for StTE 1 BENCH-SCALE TESTS ....................................... 7

2. RESULTS OF BENCH-SCALE OXIDATION TESTS................................................................ 8

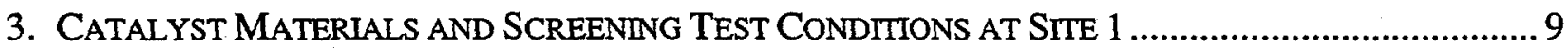

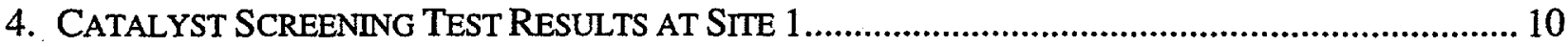

5. INITIAL CATALYST CONFIGURATION FOR LONG-TERM TESTING AT SITE $1 \ldots \ldots \ldots \ldots \ldots \ldots \ldots \ldots \ldots . . . . . . . . . . . . .11$

6. RESULTS OF THE INITIAL LONG-TERM CATALYST TEST PERIOD AT SITE 1 .............................. 12

7. SECOND CATALyst CONFIGURATION FOR LONG-TERM TESTING AT SITE 1 .......................... 14

8. RESULTS FROM THE SECOND LONG-TERM CATALYST TEST PERIOD AT SITE............................ 14

9. CATALYST CHARACTERISTICS FOR TWO MERCURY CATALYST MATERIALS

COMPARED TO CHARACTERISTICS OF SCR CATALYSTS ................................................... 17

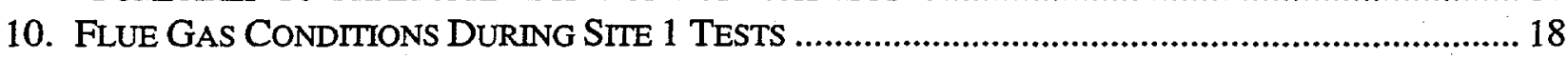

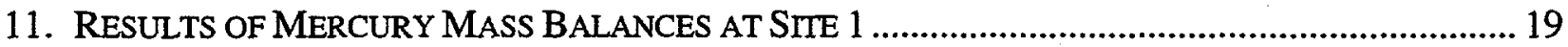

12. COMPARISON OF FGD SYSTEM INLET AND OUTLET ELEMENTAL MERCURY CONCENTRATIONS.

13. LABORATORY RESULTS FOR CATALYST MATERIALS RECOVERED FROM THE

FIELD TEST UNIT AFTER 1100 HOURS OF OPERATION AT SITE 1

14. RESUltS OF BENCH-SCALE CATALYST REGENERATION TESTS .

15. CAPACITY AND OXIDATION AT SITE 2 SIMULATED CONDITIONS AND $300^{\circ} \mathrm{F}$

FOR REAGENT AND FIELD SAMPLES RECOVERED FROM THE SECOND LONG-TERM TEST

16. DETERMINATION OF $\mathrm{SO}_{2}$ ADSORBED ON SITE 1 LONG-TERM CATALYSTS 


\section{INTRODUCTION}

The 1990 Clean Air Act Amendments mandated the Environmental Protection Agency to study the health effects caused by hazardous air pollutants (HAPs) from electric utility plants. The act also mandated a separate study of the effect of mercury emissions. Most HAPs of concern in power plants occur in the particulate phase and are therefore removed in particulate control devices. However, mercury, although emitted in extremely low concentrations, is primarily present in the vapor phase at most plants. Therefore, particulate removal devices are generally not effective at removing mercury from flue gas and alternative removal methods are needed. A number of different research programs have focused on the study of mercury emissions from power plants and methods for reducing these emissions.

The U.S. Department of Energy's Federal Energy Technology Center (DOE/FETC) is co-funding this project to further investigate a process for improving the ability of existing wet flue gas desulfurization (FGD) systems to control mercury emissions from coal-fired power plants. The project is being conducted under a cost-sharing PRDA agreement between DOE/FETC and EPRI, with Radian International as the prime contractor.

The proposed process would use a catalyst material to oxidize elemental mercury to a watersoluble mercury form. Vapor-phase mercury generally exists in two forms in utility flue gas-as elemental mercury and as water soluble, oxidized mercury (the predominant form is believed to be $\mathrm{HgCl}_{2}$ ). Previous test results have shown that wet scrubbers effectively remove oxidized mercury from the gas but are ineffective in removing elemental mercury. Since elemental mercury is present in most flue gas streams, this process can potentially improve overall mercury removal in wet scrubbers by converting the elemental mercury to a form that is more readily removed.

During Phase I of this PRDA project, several catalyst materials were identified in the laboratory as being able to oxidize elemental mercury. This ability was confirmed in short-term, slipstream field tests. Phase II of this project began in April 1998, and is further investigating the viability of the proposed process by exposing selected catalyst materials to flue gas over an extended period of time at various coal-fired power plants. This testing will be used to predict catalyst quantities required and catalyst life for future full-scale application of the technology.

This technical note describes the general technical approach for Phase II and presents Phase II results for Site 1, the first of the three planned sites. Also presented are the results of laboratory testing to screen catalyst materials for Site 1 and to investigate methods of regenerating spent catalysts from the Site 1 testing.

\section{PHASE II TECHNICAL APPROACH}

Based on promising results from Phase I of this project, DOE/FETC selected this project for further investigation in a Phase II effort: The objectives of Phase II include:

- Evaluate the ability of catalyst materials identified in Phase I to oxidize elemental mercury at various full-scale facilities; 
- Estimate the life of these catalyst materials in various flue gas streams; and

- Estimate the volume of catalyst required to achieve at least $70 \%$ oxidation of the elemental mercury in these flue gas streams.

Phase II testing is addressing two critical issues - the life of the catalyst (i.e., how long will the catalyst oxidize mercury?) and the applicability of the process for the U.S. electric utility industry (i.e., does the effectiveness of the catalysts vary for different coals?). The catalyst oxidation efficiency and life will ultimately affect the form of any subsequent commercial process and its economics. Coal effects on the process could limit the number of power plants for which the process might apply. The Phase II test program is addressing these issues by conducting longterm catalyst tests at three full-scale utility sites.

\section{Field Testing}

Figure 1 illustrates the catalyst test unit that was specifically designed to operate catalyst beds in a slipstream of flue gas from a coal-fired boiler over an extended period of time. The test unit is contained within a heated box that is mounted directly to a flue gas duct, and small enough to be easily moved from site to site.

Flue gas is continuously withdrawn from the duct through a heated glass probe and passes through a quartz filter before contacting the catalyst beds. Although the catalyst materials would be exposed to fly ash remaining in the flue gas downstream of the existing particulate control device in future full-scale systems, residual fly ash is removed in the test unit to prevent plugging and "background" oxidation. Presumably, a commercial catalyst configuration (e.g., a honeycomb) would be designed to avoid plugging with ash.

After passing through the filter, the flue gas passes through three parallel catalyst test cells. Each test cell contains two packed beds of catalyst material. The temperature of the catalyst beds are monitored and controlled by adjusting the temperature of the heated box. Orifices and differential pressure transmitters are used to monitor the gas flow rate through each test cell. The gas flow rates are adjusted with needle valves. After flowing through the cells, the flue gas passes through a condenser to remove moisture then through sample pumps. The normal superficial gas velocity through a test cell is about $18 \mathrm{ft} / \mathrm{min}$, which is similar to the gas velocity through a fabric filter in the EPRI COHPAC configuration (i.e., a pulse-jet fabric filter installed downstream of an ESP).

Since there are two catalyst beds in series in each of the three test cells, up to six different catalyst materials could potentially be tested simultaneously. However, one bed typically contains a sand bed "blank," and another cell typically has two beds containing the same catalyst material in series to provide oxidation data at two space velocities (i.e., different ratios of gas flow rate to catalyst volume). Consequently, only four different catalyst materials are typically tested at a time.

The catalyst materials are mixed with sand before being placed in the test cells. The sand helps to minimize gas flow distribution problems by providing a thicker bed and more consistent pressure drop. Test ports are located at the outlet of each catalyst bed as well as at the inlet and outlet of 


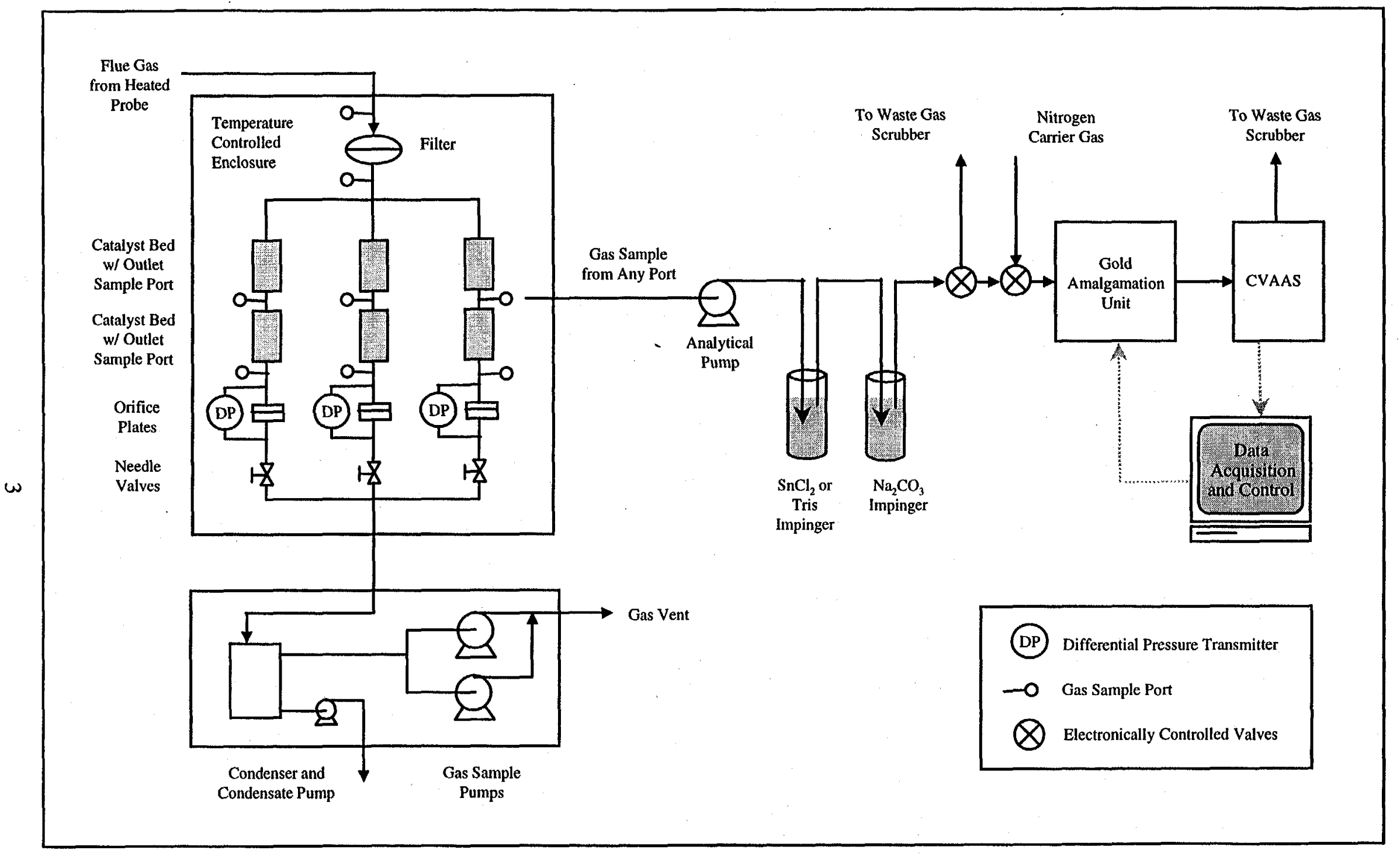

Figure 1. Catalyst Field Test Unit and Mercury Analyzer 
the quartz filter so mercury samples can be collected upstream and downstream of all catalyst beds. By measuring the change in elemental mercury concentration across each bed, the amount of mercury oxidation across each can be determined.

Mercury measurements are made using a semi-continuous mercury analyzer developed for EPRI. As shown in Figure 1, flue gas is pulled from the catalyst test unit at about $1 \mathrm{~L} / \mathrm{min}$ through a Teflon ${ }^{\circledR}$-lined pump and is passed through a series of impinger solutions. To measure total mercury in the flue gas, the impinger solutions consist of stannous chloride $\left(\mathrm{SnCl}_{2}\right)$ followed by a sodium carbonate $\left(\mathrm{Na}_{2} \mathrm{CO}_{3}\right)$ buffer. The $\mathrm{SnCl}_{2}$ solution reduces all flue gas mercury species to elemental mercury. After passing through the $\mathrm{SnCl}_{2}$ impinger, the gas flows through the $\mathrm{Na}_{2} \mathrm{CO}_{3}$ solution to remove acid gases, thus protecting the downstream, analytical gold surface. Gas exiting the impinger solutions flows through a gold amalgamation column where the mercury in the gas is adsorbed. After adsorbing mercury onto the gold for a fixed period of time (typically 10 minutes), the mercury concentrated on the gold is thermally desorbed $\left(>700^{\circ} \mathrm{C}\right)$ from the column into nitrogen and sent as a concentrated stream to a cold-vapor atomic absorption spectrophotometer (CVAAS) for analysis. Therefore, the total flue gas mercury concentration is measured semi-continuously with a 10-minute sample time followed by a 10-minute analysis period.

To measure elemental mercury in the flue gas, the stannous chloride impinger is replaced with an impinger containing tris(hydroxymethyl)aminomethane (Tris) solution. The Tris solution has been shown in other EPRI studies to capture oxidized mercury while allowing elemental mercury to pass through without being altered ${ }^{1}$. Mercury passing through the Tris solution to the gold is analyzed as described above and assumed to be only elemental mercury. The difference between the total mercury concentration (stannous chloride solution) and elemental mercury concentration (Tris solution) is taken as the oxidized mercury concentration.

Using the equipment described above, the most promising catalyst materials are being tested for six months at each of three full-scale utility power plants. At each site, an initial set of short-term screening tests is conducted to determine the best catalyst candidates for that site and to compare the performance of different catalyst materials from site to site. Based on the results of these initial screening tests, four catalyst materials are selected for long-term testing at each site. The materials are placed in the catalyst test unit and exposed to flue gas continuously over a sixmonth period. Every few weeks, performance measurements are taken to determine if oxidation has changed with time. Between performance measurements, the test unit operating conditions are monitored remotely using mobile communications. This approach will allow catalyst life to be estimated for up to four catalyst materials at three different coal-fired facilities.

The test sites are being chosen to provide a wide range of flue gas compositions and coal types. The three test sites will correspond with the three solid fossil fuels predominantly used for power generation in the U.S.: bituminous coal, subbituminous coal, and lignite. Of the installed FGD capacity in the U.S., about $48 \%$ (on a megawatt basis) is on power plants that fire bituminous coals, $40 \%$ on plants that fire subbituminous coal, and $12 \%$ on plants that fire lignite. Testing has been completed at the first site, a power plant that fires a medium-sulfur Texas lignite. Testing is 
just beginning at the second site, which fires a low-sulfur Powder River Basin subbituminous coal. The third site has not been selected, but will fire a medium- or high-sulfur bituminous coal.

\section{Laboratory Bench-scale Testing}

Laboratory tests are also being conducted to support the field work. The laboratory bench-scale unit is shown in Figure 2. The typical test approach consists of passing a simulated flue gas containing elemental mercury across a fixed-bed reactor that contains catalyst material. The gas exiting the fixed bed is analyzed semi-continuously by the same analytical technique described above to determine the fraction of inlet elemental mercury oxidized across the bed.

The simulated flue gas is prepared from reagent gases using calibrated flow meters. Elemental mercury is added to the simulated flue gas by passing nitrogen carrier gas across a mercury diffusion cell that contains an elemental mercury $\left(\mathrm{Hg}^{0}\right)$ permeation tube. The amount of diffused mercury is controlled with the flow of nitrogen through and the temperature of the diffusion cell. The mercury-containing nitrogen is then mixed with other flue gas components $\left(\mathrm{SO}_{2}, \mathrm{HCl}, \mathrm{NO}\right.$, $\mathrm{O}_{2}, \mathrm{CO}_{2}$, and $\mathrm{H}_{2} \mathrm{O}$ ) at a controlled temperature before the gas enters the fixed-bed reactor.

The fixed-bed reactor consists of a mixture of catalyst material and sand placed in a temperaturecontrolled, vertical Pyrex column, typically yielding a bed length of about 1.75 inches. Gas exiting the fixed bed is analyzed to determine the percentage of inlet elemental mercury oxidized across the bed. The gas rate is typically about $1 \mathrm{~L} / \mathrm{min}$ at $300^{\circ} \mathrm{F}$, which results in a superficial gas velocity through the bed of about $20 \mathrm{ft} / \mathrm{min}$.

The bench-scale unit is used to simulate the flue gas conditions of each full-scale test site before going to the field. This provides information about the expected effects of flue gas composition on oxidation before beginning the field tests. The bench-scale unit is also being used to investigate the regeneration of spent catalysts. Spent catalysts are first regenerated by exposure to various atmospheres at elevated temperatures, then tested for activity towards mercury oxidation in simulated flue gas at $275-300^{\circ} \mathrm{F}$. The bench-scale unit may subsequently be used develop a better understanding of oxidation and deactivation mechanisms.

\section{SITE 1 RESULTS}

Phase II results to date include results for the completed long-term test series at Site 1 and related laboratory-scale catalyst screening and regeneration test results. These results are discussed below.

Site 1 is a large ( $>500 \mathrm{MW})$ wall-fired unit that fires Texas lignite. It has an ESP for particulate control and a wet limestone FGD system. It was selected due to its relatively high concentration of elemental mercury and due to successful results at that site during Phase I.

Prior to testing at Site 1, a number of catalyst materials were screened for activity in short-term lab tests at simulated Site 1 flue gas conditions. These results were used to select the catalyst materials that appeared to be most active for the Site 1 flue gas. At Site 1, the selected catalyst 


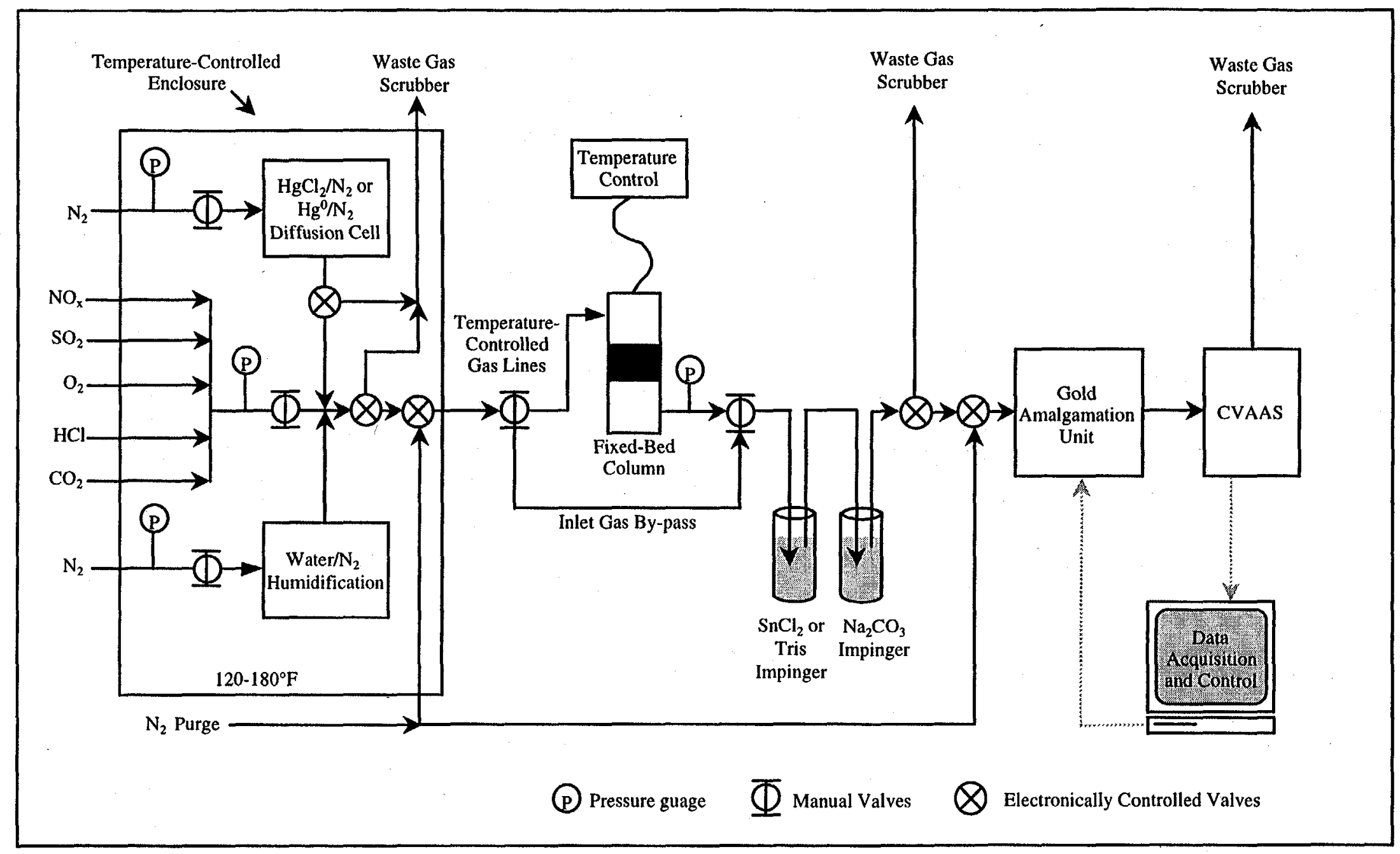

Figure 2. Bench-Scale, Fixed-Bed Mercury Oxidation Test Unit 
materials were again screened for activity with the actual flue gas. From the field screening test results, four catalyst materials were selected for long-term testing, which began at the end of May 1998. After about 1000 hours of operation, the initial catalysts appeared to have lost activity. They were replaced at higher catalyst loading and the tests were restarted. This second test continued through mid-December. The Site 1 lab screening, field screening and long-term test results are discussed below.

\section{Site 1 Lab Screening Tests}

Prior to going to the field at each site, bench-scale tests are conducted to screen catalyst materials at simulated flue gas conditions similar to that site. This allows the field effort to be limited to only the more active catalysts for a particular flue gas composition. Also, as more comparison data are available for lab results with synthetic flue gas versus field results with the actual flue gas, it should be possible to quantify the accuracy of the bench-scale test apparatus as a tool for screening catalysts.

Laboratory tests were carried out prior to field testing at Site 1 by reacting known masses of catalyst with a mercury-containing, simulated flue gas at $300^{\circ} \mathrm{F}$. Table 1 lists the flue gas conditions tested. The effluent gas was monitored using the semi-continuous mercury analyzer to measure the concentration of total mercury exiting the column. Tests were run until adsorption equilibrium was reached. At this point the concentration of elemental mercury in the effluent gas was measured. Comparison of elemental and total mercury concentrations enabled the extent of oxidation across the catalysts to be calculated.

Table 1. Simulated Flue Gas Conditions for Site 1 Bench-Scale Tests

\begin{tabular}{||c|c|c|}
\hline Flue Gas Tested & Site \#1 Simulation & Baseline \#5 \\
\hline $\mathrm{HCl}(\mathrm{ppm})$ & 1 & 50 \\
\hline $\mathrm{SO}_{2}(\mathrm{ppm})$ & 1400 & 1600 \\
\hline $\mathrm{CO}_{2}(\%)$ & 12 & 12 \\
\hline $\mathrm{H}_{2} \mathrm{O}(\%)$ & 8 & 7 \\
\hline $\mathrm{NO}_{r}(\mathrm{ppm})$ & 200 & 400 \\
\hline $\mathrm{O}_{2}(\%)$ & 6 & 6 \\
\hline Catalyst temperature $\left({ }^{\circ} \mathrm{F}\right)$ & 300 & 275 \\
\hline Gas flow rate $(\mathrm{L} / \mathrm{min})$ & 1.0 & 1.0 \\
\hline
\end{tabular}

Several tests were also included with two catalyst materials, the FGD and Pilot-5 carbons, at "Baseline \#5" conditions. The objective of these tests was to investigate the effect of $\mathrm{NO}_{x}$ in the gas on the ability of the carbons to oxidize elemental mercury, as Phase I tests with these samples had been conducted at similar conditions but without $\mathrm{NO}_{\mathrm{x}}$ in the gas.

The catalyst masses tested in each case were based upon previous results with these materials. In general, carbon materials were tested at a loading of $20 \mathrm{mg}$ in the sand bed while treating 1 $\mathrm{L} / \mathrm{min}$ of simulated gas. Fly ashes and metal-based catalysts were tested at the same gas rate but a ten-fold higher, 200-mg loading in the sand bed. 
The results of the bench-scale tests are listed in Table 2. Each carbon tested, with the exception of ACF-20-650 (ISGS-3a), showed oxidation levels over 90\%. The IAC carbon and ACF-20-400 (ISGS-3) carbon fibers also showed high levels of mercury adsorption. Two fly ash samples (Niles pond ash and King fly ash) showed over 95\% oxidization; lower oxidation levels were observed with the other ashes. The fly ash samples showed low adsorption capacities at these conditions.

Table 2. Results of Bench-Scale Oxidation Tests

\begin{tabular}{|c|c|c|c|}
\hline $\begin{array}{c}\text { Sample } \\
\text { Name } \\
\end{array}$ & $\begin{array}{l}\text { Sorbent } \\
\text { Mass } \\
\text { (mg) } \\
\end{array}$ & $\begin{array}{c}\text { Adsorbed } \\
\text { Mercury } \\
\text { ( } \mu \mathrm{g} \text { Hg/g sorbent) }\end{array}$ & $\begin{array}{l}\text { Percent } \\
\text { Mercury } \\
\text { Oxidized } \\
\end{array}$ \\
\hline \multicolumn{4}{|c|}{ Site 1 Simulation Test Results } \\
\hline FGD carbon & 20 & * & 95 \\
\hline FGD carbon repeat & 20 & 201 & 100 \\
\hline Pilot -5 carbon & 20 & 202 & 91 \\
\hline IAC carbon & 20 & 1780 & 96 \\
\hline $\mathrm{Fe} / \mathrm{Cr}$ catalyst & 200 & 6 & 7 \\
\hline Magnetite & 200 & 78 & 23 \\
\hline Pd/Alumina catalyst & 200 & 12 & 91 \\
\hline PdI reagent & 200 & 12 & 98 \\
\hline ACF-20-400 carbon fibers (ISGS-3) & 20 & 1451 & 100 \\
\hline ACF-20-650 carbon (ISGS-3a) & 20 & 1084 & 17 \\
\hline AC-T-2 (ISGS-4) & 20 & 143 & 97 \\
\hline Valmy fly ash (SBA\#3) & 200 & 1 & 14 \\
\hline ECTC-ESP field 1 fly ash (BA\#2b) & 200 & 2 & 49 \\
\hline Niles pond ash (BA\#3) & 200 & 8 & 96 \\
\hline King fly ash (SBA\#4) & 200 & 2 & 97 \\
\hline NPS high LOI ash (SBA\#5) & 200 & * & $*$ \\
\hline NPS high LOI ash (SBA\#5) & 200 & ** & ** \\
\hline \multicolumn{4}{|c|}{ Baseline \#5 Test Results } \\
\hline FGD carbon & 20 & 519 & 96 \\
\hline FGD carbon & 20 & 620 & No data \\
\hline Pilot-5 carbon & 20 & 348 & 95 \\
\hline
\end{tabular}

* Operational problem prevented some or all pertinent data from being obtained.

** Test showed no mercury breakthrough after 2800 minutes; results were presumed suspect.

The metal-containing catalysts showed differing results, with the palladium samples showing high oxidation percentages but the iron samples showing poor results. The iron-chrome catalyst and magnetite both showed much lower mercury oxidation than during Phase I tests. This suggests that some gas parameter, such as the lower $\mathrm{HCl}$ concentration or the presence of $\mathrm{NO}_{\mathrm{x}}$, was responsible for inhibiting the iron catalysts. This further suggests that flue gas components have a large impact on the performance of the catalysts. The results for the iron-containing catalysts are consistent with the flue gas chemistry of Site 1, considering that the Site 1 fly ash is 
rich in iron yet the mercury oxidation percentage is relatively low (i.e., the iron-rich fly ash is apparently not an effective in situ oxidation catalyst).

As noted above, several tests were performed under "Baseline \#5" conditions to investigate the effect of $\mathrm{NO}_{\mathrm{x}}$ on mercury oxidation as well as to check the operation of the system. These tests indicated that the adsorption capacities of FGD and Pilot-5 carbon decreased by a factor of two to four (from previous values of over $1200 \mu \mathrm{g} / \mathrm{g}$ ) in the presence of $400 \mathrm{ppm} \mathrm{NO}$. The oxidation percentages, however, were still very high. These results suggest that $\mathrm{NO}_{\mathrm{x}}$ in the flue gas has an adverse effect on carbon adsorption capacity, but may not affect oxidation activity.

\section{Catalyst Screening Tests at Site 1}

In May 1998, the field test unit was used to screen catalyst materials under actual Site 1 flue gas conditions. Based on the lab results, it was decided to field test all of the carbons except ACF-20650 (ISGS-3a), which performed poorly in the lab, both palladium-based catalysts, and four of the fly ashes. These four were the NPS high LOI fly ash, the Niles pond ash, the ECTC fly ash, and the King fly ash. The iron-based catalysts were not tested in the field due to their poor performance on the simulated flue gas.

Table 3 summarizes the catalyst materials and conditions tested during the Site 1 catalyst screening tests. The indicated mass was mixed with 75 grams of sand and the mixture was placed in the test cell. Some catalysts were placed in two packed beds in series while others were placed in only one bed. Catalyst materials with more than one mass reported in Table 3 were tested as two beds in series. One of the six packed beds in the apparatus contained only sand to serve as a blank.

Table 3. Catalyst Materials and Screening Test Conditions at Site 1

\begin{tabular}{|c|c|c|c|c|}
\hline Catalyst Samples & Description & $\begin{array}{c}\text { Mass } \\
(\mathbf{m g})\end{array}$ & $\begin{array}{c}\text { Tested } \\
\left({ }^{\circ} \mathbf{F}\right)\end{array}$ & $\begin{array}{c}\text { Gas Rate } \\
\text { (L/min @ } \\
\mathbf{8 5} \text { F) }\end{array}$ \\
\hline FGD carbon & Carbon-based & 75,150 & 300 & 5 \\
\hline IAC carbon & Carbon-based & 75,150 & 300 & 5 \\
\hline Pilot-5 & Carbon-based & 75 & 300 & 5 \\
\hline IPAC-5 (ISGS-1) & Carbon-based & 75,150 & 300 & 5 \\
\hline ACF-20-400 (ISGS-3) & Carbon-based & 75,150 & 300 & 5 \\
\hline TDAC-L-31 (ISGS-4) & Carbon-based & 75,150 & 300 & 5 \\
\hline Palladium on alumina & Palladium-based & 750,1500 & 300 & 5 \\
\hline PdI & Palladium-based & 750 & 300 & 5 \\
\hline ECTC ESP field 1 & Bituminous ash & 3750 & 300 & 5 \\
\hline Niles pond ash & Bituminous ash & 750,1500 & 300 & 5 \\
\hline King fly ash & Subbituminous ash & 3750 & 300 & 5 \\
\hline NPS high LOI fly ash & Subbituminous ash & 750,1500 & 300 & 5 \\
\hline
\end{tabular}


Table 4 summarizes the initial catalyst screening test results obtained at Site 1 and compares them to the results with those catalyst materials obtained in the lab at simulated Site 1 flue gas composition. In general, the lab results are consistent with the field results, although for three samples, ACF-20-400 (ISGS-3), Niles pond ash, and King fly ash, the lab result was significantly higher than the field result. Two field sand blank measurements were made which resulted in an average oxidation of $5.8 \%$. This indicates that the sand mixed with each catalyst material does not significantly affect oxidation.

Table 4. Catalyst Screening Test Results at Site 1

\begin{tabular}{|c|c|c|c|c|c|c|c|c|}
\hline \multirow[b]{2}{*}{ Sorbent } & \multicolumn{3}{|c|}{ Site 1 Inlet } & \multicolumn{3}{|c|}{ Site 1 Outlet } & \multicolumn{2}{|c|}{$\begin{array}{c}\mathrm{Hg}^{0} \text { Oxidized } \\
\text { by Catalyst }\end{array}$} \\
\hline & $\begin{array}{l}\text { Total Hg } \\
\left(\mu \mathrm{g} / \mathrm{Nm}^{3}\right)\end{array}$ & $\begin{array}{c}\mathbf{H g}^{\mathbf{0}} \\
\left(\mu \mathrm{g} / \mathrm{Nm}^{\mathbf{3}}\right)\end{array}$ & $\begin{array}{c}\% \\
\text { Oxidized } \\
\end{array}$ & $\begin{array}{l}\text { Total Hg } \\
\left(\mu \mathrm{g} / \mathrm{Nm}^{3}\right)\end{array} \mid$ & $\begin{array}{c}\mathbf{H g}^{\mathbf{0}} \\
\left(\mu \mathrm{g} / \mathrm{Nm}^{3}\right)\end{array}$ & $\begin{array}{c}\% \\
\text { Oxidized } \\
\end{array}$ & $\begin{array}{c}\text { Site 1 } \\
\text { Result } \\
(\%)\end{array}$ & $\begin{array}{c}\text { Lab } \\
\text { Result } \\
(\%)^{*}\end{array}$ \\
\hline Sand & 9.8 & 7.3 & 25.5 & 10.1 & 6.7 & 33.7 & 8.2 & - \\
\hline Sand & 18.1 & 9.0 & 50.3 & 17.5 & 8.7 & 50.3 & 3.3 & 3 \\
\hline FGD carbon, both beds & 9.8 & 7.3 & 25.7 & 10.6 & 0.0 & 100.0 & 100.0 & 100 \\
\hline FGD carbon, one bed & 9.8 & 7.3 & 25.7 & 10.6 & 0.0 & 100.0 & 100.0 & 100 \\
\hline IAC carbon, both beds & 10.2 & 7.5 & 26.5 & 10.6 & 0.3 & 97.6 & 96.7 & 96 \\
\hline IAC carbon, one bed & 10.2 & 7.5 & 26.5 & 10.6 & 0 & 100.0 & 100.0 & 96 \\
\hline Pilot 5 carbon, one bed & 10.2 & 7.5 & 26.5 & 11.0 & 0.5 & 95.5 & 93.3 & 91 \\
\hline IPAC-5, both beds & 7.0 & 3.7 & 47.1 & 6.5 & 0.2 & 96.9 & 94.6 & - \\
\hline IPAC-5, one bed & 7.0 & 3.7 & 47.1 & 6.5 & 0.25 & 96.1 & 93.2 & - \\
\hline ACF-20-400, both beds & 8.8 & 4.1 & 53.1 & 7.9 & 1.6 & 80.4 & 62.2 & 100 \\
\hline ACF-20-400, one bed & 8.8 & 4.1 & 53.1 & 7.9 & 1.9 & 75.8 & 53.2 & 100 \\
\hline TDAC-L-31, both beds & 18.1 & 9.0 & 50.3 & 13.6 & 0.1 & 99.3 & 98.9 & 97 \\
\hline TDAC-L-31, one bed & 18.1 & 9.0 & 50.3 & 14.2 & 0.3 & 97.9 & 96.7 & 97 \\
\hline $\begin{array}{l}\text { Pd on alumina, both } \\
\text { beds }\end{array}$ & 19.0 & 9.8 & 48.4 & 14.6 & 1.0 & 93.5 & 90.3 & 91 \\
\hline $\mathrm{Pd}$ on alumina, one bed & 19.0 & 9.8 & 48.4 & 14.6 & 2.3 & 83.8 & 76.4 & 91 \\
\hline PdI, one bed & 18.1 & 9.0 & 50.3 & 19.9 & 1.2 & 94.0 & 86.7 & 98 \\
\hline $\begin{array}{l}\text { ECTC ESP Field 1, one } \\
\text { bed }\end{array}$ & 26.1 & 15.3 & 41.4 & 23.0 & 6.7 & 70.9 & 56.2 & 49 \\
\hline $\begin{array}{l}\text { Niles pond ash, both } \\
\text { beds }\end{array}$ & 21.5 & 16.2 & 24.7 & 23.3 & 6.3 & 73.0 & 61.1 & 96 \\
\hline Niles pond ash, one bed & 21.5 & 16.2 & 24.7 & 23.3 & 6.7 & 71.2 & 58.6 & \\
\hline King fly ash, one bed & 8.8 & 4.1 & 53.4 & 6.6 & 1.7 & 74.2 & 58.5 & 97 \\
\hline NPS high LOI fly ash & 21.5 & 16.2 & 24.7 & 19.7 & 0.0 & 100.0 & 100.0 & *** \\
\hline NPS high LOI fly ash & 21.5 & 16.2 & 24.7 & 19.7 & 0.0 & 100.0 & 100.0 & $* *$ \\
\hline
\end{tabular}


In addition, the total mercury concentrations at the inlet and outlet of the catalyst beds were essentially equal during each test except when testing catalyst materials TDAC-L-31 (ISGS-4) and palladium on alumina. The lower outlet mercury concentrations obtained during these tests most likely indicate that mercury was being adsorbed by the catalyst material when the measurements were taken. During all of the other tests, adsorption equilibrium was achieved before taking oxidation measurements, as indicated by essentially equal inlet and outlet mercury concentrations.

All of the carbon-based catalysts achieved greater than $90 \%$ elemental mercury oxidation at Site 1 with the exception of carbon fiber catalyst ACF-20-400 (ISGS-3). This material showed high oxidation percentages in the lab but not in the field. The palladium-based catalysts also showed reasonably high oxidation percentages, but their performance was lower than that of the carbonbased materials. The fly ash samples were only able to achieve about $60 \%$ oxidation with the exception of the NPS fly ash, which is known to have a very high loss on ignition. These data suggest that the unburned carbon content in the NPS ash affects mercury oxidation, since its performance was similar to that of the carbon-based materials (although it was tested at a much higher catalyst loading).

Based on the field screening test results, the following materials were selected for long-term testing at Site 1: FGD Carbon, IPAC-5 Carbon (ISGS-1), TDAC-L-31 Carbon (ISGS-4), and NPS high LOI fly ash. All four exhibited high oxidation percentages of elemental mercury (93\% to $100 \%$ ) in the short-term screening tests. Table 5 illustrates how these materials were configured in the catalyst test unit. The long-term test commenced at the end of May, with the heated box temperature set at $300^{\circ} \mathrm{F}$ and the flow rate through each cell set at $5 \mathrm{~L} / \mathrm{min}$ (as measured downstream at ambient temperature).

Table 5. Initial Catalyst Configuration for Long-Term Testing at Site 1

\begin{tabular}{|l|c|c|c|}
\hline & Test Cell \#1 & Test Cell \#2 & Test Cell \#3 \\
\hline Packed bed \#1 & $75 \mathrm{~g}$ of sand & $\begin{array}{c}0.25 \mathrm{~g} \text { FGD carbon in } \\
75 \mathrm{~g} \text { sand }\end{array}$ & $\begin{array}{c}0.25 \mathrm{~g} \text { TDAC-L-31 } \\
\text { (ISGS-4) in 75 g sand }\end{array}$ \\
\hline Packed bed \#2 & $\begin{array}{c}1.5 \mathrm{~g} \text { NPS high LOI } \\
\text { fly ash in 75 g sand }\end{array}$ & $\begin{array}{c}0.25 \mathrm{~g} \text { FGD carbon in } \\
75 \mathrm{~g} \text { sand }\end{array}$ & $\begin{array}{c}0.25 \mathrm{~g} \text { IPAC-5 (ISGS-1) } \\
\text { in 75 g sand }\end{array}$ \\
\hline
\end{tabular}

As noted in Table 5, one of the six packed beds in the apparatus contained only sand to serve as a blank, and one test cell had two beds containing the same catalyst material (FGD Carbon) in series. Also note that the activated carbon materials were tested at lower dosages than the other materials due to their higher activity as observed in short-term testing.

\section{Long-term Test Results}

Table 6 summarizes the results of mercury oxidation measurements for these catalysts over seven weeks of flue gas treatment at Site 1 . Note that the initial mercury oxidation percentages in the table are based on the field screening test results for these catalysts. Oxidation measurements 
Table 6. Results of the Initial Long-Term Catalyst Test Period at Site 1

\begin{tabular}{|c|c|c|c|c|c|}
\hline & \multirow{2}{*}{$\begin{array}{c}\text { Initial } \\
\text { Performance } \\
\text { (screening } \\
\text { test) } \mathbf{H g}^{\mathbf{0}} \\
\% \text { Oxidation) }\end{array}$} & \multicolumn{2}{|c|}{$\begin{array}{c}\text { Performance After } 5 \text { Weeks } \\
\text { (800 hours) }\end{array}$} & \multicolumn{2}{|c|}{$\begin{array}{c}\text { Performance After } 7 \text { Weeks } \\
\text { (1100 hours) }\end{array}$} \\
\hline & & $\begin{array}{c}\mathrm{Hg}^{0} \text { Conc. at } \\
\text { Bed Outlet, } \\
\mu \mathrm{g} / \mathrm{Nm}^{3}\end{array}$ & $\begin{array}{c}\mathbf{H g}^{\mathbf{0}} \\
\text { \% Oxidation }\end{array}$ & $\begin{array}{c}\mathbf{H g}^{0} \text { Conc. at } \\
\text { Bed Outlet, } \\
\mu \mathrm{g} / \mathrm{Nm}^{3}\end{array}$ & $\begin{array}{c}\mathbf{H g}^{\mathbf{0}} \\
\text { \% Oxidation }\end{array}$ \\
\hline Sand blank & $3.3-8.1$ & 9.53 & - & 7.07 & - \\
\hline $\begin{array}{l}\text { NPS high LOI } \\
\text { fly ash }\end{array}$ & $100^{* *}$ & 7.41 & 22 & 7.17 & 0 \\
\hline $\begin{array}{l}\text { FGD carbon } \\
\left(1^{\text {st }} \text { bed }\right)\end{array}$ & $100^{* *}$ & ND & ND & $>7.07 ?$ & 0 \\
\hline $\begin{array}{l}\text { FGD carbon } \\
\left(2^{\text {nd }} \text { bed }\right)\end{array}$ & $100^{* *}$ & ND & ND & 5.24 & 26 \\
\hline $\begin{array}{l}\text { TDAC-L-31 } \\
\text { (ISGS-4) }\end{array}$ & $97 * *$ & 4.78 & 53 & 6.12 & 13 \\
\hline $\begin{array}{l}\text { IPAC-5 } \\
\text { (ISGS-1) }\end{array}$ & $95 * *$ & 5.65 & 41 & 7.35 & 0 \\
\hline
\end{tabular}

* All results are corrected to account for the observed mercury oxidation across the sand bed blank.

** Screening test results are for two beds, but at a lower catalyst loading; total catalyst mass was $60 \%$ of the mass in one bed during the long term test.

$\mathrm{ND}$ - not determined due to analytical problems.

were not made immediately after the long-term test began, as it was expected to take several days for the fresh catalysts to reach mercury adsorption equilibrium (stop adsorbing mercury) so that oxidation percentages could be measured.

Also note that the oxidation percentages shown in Table 6 are calculated from the decrease in elemental mercury across the catalyst beds, and do not just represent the total mercury oxidation percentage at the bed outlet. The latter would generally be a higher percentage because a portion of the total mercury content in the gas is already oxidized before entering the catalyst test unit. The percentages shown also account for any observed mercury oxidation across the sand blank, to account for any contribution to elemental mercury oxidation by the sand content in each bed.

The semi-continuous analyzer is not completely automated to allow continued unmanned operation. Therefore, oxidation measurements were only made when Radian personnel returned to Site 1. After putting the catalysts in service at the end of May, the first return trip was made at the end of June, after the catalyst materials had seen about five weeks of flue gas exposure.

Problems were encountered with the measurement of total mercury (i.e., using $\mathrm{SnCl}_{2}$ impingers) which resulted in severe fouling of the gold amalgamation column. Although it has not been determined what caused this problem, it is believed that poor mass transfer in the analyzer's impingers was partially responsible. Although the standard-size impingers used were ideal for containing large volumes of solution to allow longer-term analyzer operation, they are designed 
for much higher gas flow rates than were being used. Smaller impingers were obtained for subsequent trips and appeared to improve mass transfer.

Because of the problems associated with the "total" mercury measurements, catalyst sampling focused on the measurement of elemental mercury (i.e., using Tris impingers). Assuming the absorption equilibrium had been reached, these measurements were sufficient for determining oxidation across each catalyst bed. The results obtained downstream of each catalyst were compared to those downstream of the sand blank sample to indicate percent oxidation. The results indicated that the elemental mercury oxidation by each sample had decreased substantially since the long-term test began. Again, however, additional analytical problems made it difficult to draw firm conclusions.

FGD Carbon results were not obtained due to analytical problems. This was due to system contamination in which high residual mercury levels remained in the flow system. This was apparent when the inlet gas was switched from flue gas to air and the measured mercury remained high. The residual mercury was confirmed to be present on the glass surfaces of the impingers; all impingers were affected. As with the fouling problems described above, this problem suggests the ability of some flue gas species to pass through the impinger train causing unwanted reactions with vessel (or gold) surfaces. These problems were later minimized by using smaller impingers with better gas contact characteristics at the flow rates tested and less total exposed glass surface area. It was decided to abort performance measurements on July 2 until new glassware was obtained. Since the actual catalyst performance was unclear, the long-term tests were allowed to continue.

The next sampling trip was in mid-July, after seven weeks of flue gas treatment, and with new smaller impingers used with the semicontinuous mercury analyzer. Total mercury measurements were still problematic, but the elemental mercury measurements were more reliable than on the previous trip. The elemental mercury measurements indicated that the loss of activity was even greater than at the end of June. Of the five catalyst beds, only the downstream FGD Carbon bed and the TDAC-L-31 (ISGS-4) bed (which was in the upstream position) retained any activity.

It was decided to restart the tests, with an order of magnitude greater catalyst content in the sand beds. The two experimental carbons, TDAC-L-31 (ISGS-4) and IPAC-5 (ISGS-1), were replaced with a commercially available carbon (IAC Carbon) that had seen success in other testing and a commercially available palladium catalyst material (palladium on alumina). The latter was to provide more diversity in the catalyst types being tested, in case the carbon-based catalysts were specifically affected by a component in the Site 1 flue gas. In the initial catalyst screening tests at Site 1 , the palladium-based catalyst was observed to achieve $90.3 \%$ oxidation of elemental mercury across two beds (although at only $6 \%$ of the total catalyst loading used in the second long-term test), while IAC Carbon achieved essentially $100 \%$ oxidation. The catalyst configuration for the restart of the long-term test at Site 1 is summarized in Table 7.

This catalyst charge remained in operation for the remainder of the long-term test period, approximately five months. This time period amounted to almost 3500 hours of operation, and catalyst exposure to approximately 600 to $620 \mathrm{Nm}^{3}$ of flue gas. The catalyst bed oxidation results 
Table 7. Second Catalyst Configuration for Long-Term Testing at Site 1

\begin{tabular}{|c|c|c|c|}
\hline & Test Cell \#1 & Test Cell \#2 & Test Cell \#3 \\
\hline Packed bed \#1 & $\begin{array}{c}2.5 \mathrm{~g} \text { FGD carbon } \\
\text { in 75 g sand }\end{array}$ & $75 \mathrm{~g}$ of sand & $\begin{array}{c}15 \mathrm{~g} \text { palladium on } \\
\text { alumina in } 75 \mathrm{~g} \text { sand }\end{array}$ \\
\hline Packed bed \#2 & $\begin{array}{c}2.5 \mathrm{~g} \text { FGD carbon } \\
\text { in 75 g sand }\end{array}$ & $\begin{array}{c}14 \mathrm{~g} \text { NPS high LOI } \\
\text { fly ash in 75 } \mathrm{g} \text { sand }\end{array}$ & $\begin{array}{c}2.5 \mathrm{~g} \text { IAC carbon in } \\
75 \mathrm{~g} \text { sand }\end{array}$ \\
\hline
\end{tabular}

over this five-month period are summarized in Table 8. More detailed measurement results are presented in Appendix A.

Table 8. Results from the Second Long-Term Catalyst Test Period at Site

\begin{tabular}{|c|c|c|c|c|c|}
\hline & $\begin{array}{c}\text { Initial } \\
\text { Performance } \\
\text { (Screening } \\
\text { Tests) }\end{array}$ & $\begin{array}{c}\text { Performance } \\
\text { After 6-7 } \\
\text { Weeks }\end{array}$ & $\begin{array}{c}\text { Performance } \\
\text { After } 14 \\
\text { Weeks }\end{array}$ & $\begin{array}{c}\text { Performance } \\
\text { After } 18 \\
\text { Weeks }\end{array}$ & $\begin{array}{c}\text { Performance } \\
\text { After } 21 \\
\text { Weeks }\end{array}$ \\
\hline $\begin{array}{l}\text { Inlet total } \\
\text { Mercury, } \mu \mathrm{g} / \mathrm{Nm}^{3}\end{array}$ & $7.0-26.1$ & 9.8 & $15-27$ & $31-35$ & 27 \\
\hline $\begin{array}{l}\text { Inlet elemental } \\
\text { Mercury, } \mu \mathrm{g} / \mathrm{Nm}^{3}\end{array}$ & $3.7-16.2$ & 5.4 & $8.3-9.3$ & 17.8 & 3.7 \\
\hline $\begin{array}{l}\text { Inlet mercury } \\
\text { Oxidation, } \%\end{array}$ & $25-50$ & 45 & $45-66$ & 49 & 86 \\
\hline \multicolumn{6}{|c|}{ Elemental Mercury Oxidation Across Catalyst Beds, \%* } \\
\hline Sand blank & $3.3-8.1$ & 7 & $9-12$ & 23 & 0 \\
\hline $\begin{array}{l}\text { NPS high LOI fly } \\
\text { ash }\end{array}$ & $100^{* *}$ & 36 & 82 & 73 & 0 \\
\hline $\begin{array}{l}\text { FGD carbon } \\
\left(1^{\text {st }} \text { bed }\right)\end{array}$ & $100 * *$ & 66 & 45 & 0 & 89 \\
\hline $\begin{array}{l}\text { FGD carbon } \\
\left(2^{\text {nd }} \text { bed }\right)\end{array}$ & $100^{* *}$ & 81 & $42-59$ & 0 & 0 \\
\hline $\begin{array}{l}\text { Palladium on } \\
\text { alumina }\end{array}$ & $90 * *$ & ND & 82 & 0 & 0 \\
\hline IAC carbon & $97 * *$ & $\mathrm{ND}$ & 76 & 0 & 76 \\
\hline $\begin{array}{l}\text { Catalyst bed } \\
\text { temperature, }\left({ }^{\circ} \mathrm{F}\right)\end{array}$ & 300 & 300 & 300 & 220 & 300 \\
\hline Hours in operation & 24 & 1000 & $2300-2400$ & $3027-3055$ & $3477-3488$ \\
\hline
\end{tabular}

* All results are corrected to account for the observed mercury oxidation across the sand bed blank.

** Screening test results are for two beds, but at a much lower catalyst loading; total catalyst mass is $6 \%$ of the mass in one bed during the second long term test.

ND - not determined due to analytical problems.

The results in Table 8 show that the increases in catalyst loading significantly increased catalyst life. After approximately 1000 hours, which is equivalent to when the first test ended, three of the catalyst beds retained substantial activity. The other two were not measured because of 
analytical difficulties. After approximately 2350 hours, all of the catalysts retained a substantial amount of activity. The FGD Carbon beds retained about half of their original activity, while the other catalysts retained $75 \%$ of their original activity or greater. The ash sample (NPS high LOI fly ash) showed substantially greater activity than at 1000 hours, which suggests that either the $1000-\mathrm{hr}$ or $2350-\mathrm{hr}$ data were erroneous.

For the latter periods, test equipment and sampling problems make it difficult to interpret the catalyst activity results. At approximately 3000 hours, all but the ash sample (NPS high LOI fly ash) appeared to have lost all of their activity towards mercury oxidation. However, one of the heat plates used to maintain the temperature of the box in which the catalysts were located had failed, lowering the catalyst bed temperature from the desired value of $300^{\circ} \mathrm{F}$ to $220^{\circ} \mathrm{F}$. A suspected mechanism for loss of catalyst activity is that species in the flue gas condense, react and/or adsorb on the catalyst surface, thus blocking active sites for catalysis. The lower temperature that resulted from the failed heat plate would have certainly exacerbated tendencies for flue gas species such as sulfuric acid or selenium to adsorb and/or condense on catalyst surfaces, and may have caused a premature loss of activity.

The heater plate was replaced, and the catalysts were left in operation for about 450 hours before the final measurements were made. The final measurements were confounded by an apparent mercury oxidation bias. The mercury concentrations at the test unit inlet, as measured by the semi-continuous analyzer, indicated $86 \%$ oxidation in the inlet gas. This was a higher oxidation percentage than was ever previously measured at Site 1 , and was higher than was measured the next day by a manual method [the Ontario Hydro or $(\mathrm{KCl})$ method]. The high oxidation percentage at the test unit inlet suggests either an analytical bias, or oxidation of mercury species across the particulate filter just upstream of the inlet to the test unit. Subsequent laboratory measurements suggest the former, as elemental mercury was observed to be oxidized as it passed through the pump used for the semi-continuous mercury analyzer in the field.

At any rate, two of the carbon-based catalyst beds showed restored activity after the catalyst operating temperature had been returned to $300^{\circ} \mathrm{F}$ for 450 hours. However, these results are suspect because of the apparent bias in the oxidation numbers. An imminent boiler outage did not allow time to troubleshoot this bias in the field. Instead, the catalyst materials were recovered to be tested in the laboratory apparatus for remaining activity in a synthetic flue gas and to be regenerated, if possible.

\section{Catalyst Life Projections}

A performance target for this project has been to achieve $70 \%$ oxidation of elemental mercury for up to one year of operation, without requiring catalyst regeneration over that time period. The results from Site 1 for FGD Carbon are illustrated in Figure 3, and show that the FGD Carbon catalyst material fell short of that target. With two beds in series, the first long term test period at Site 1 showed that FGD Carbon had a useful life of less than 500 hours, while the second test period (prior to the low temperature excursion) showed a useful life of about 1700 hours. It appears that another order of magnitude increase in catalyst loading would be required for FGD 


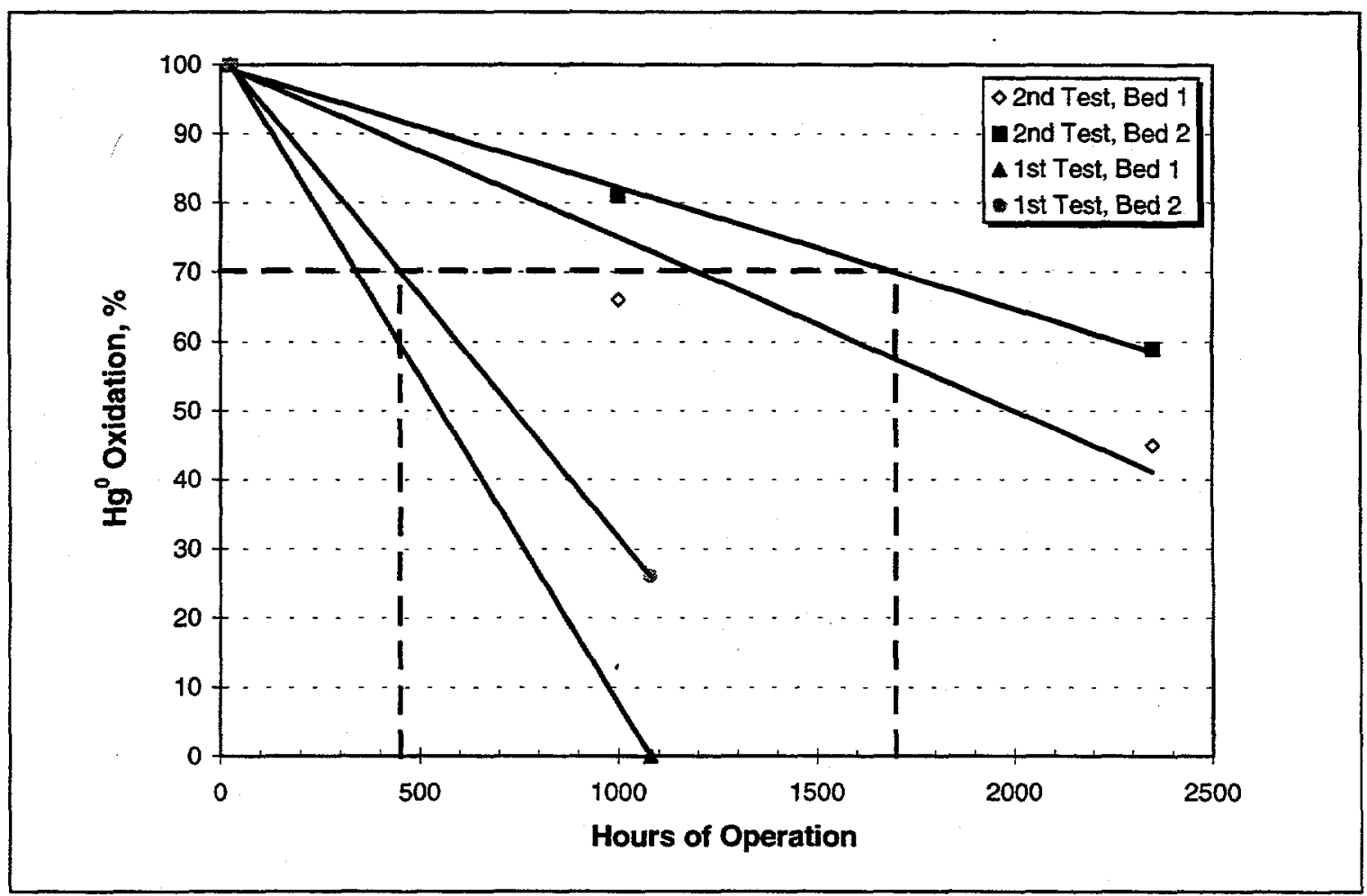

Figure 3. Site 1 Catalyst Activity Results for FGD Carbon

Carbon to approach one year of operation at $70 \%$ oxidation of elemental mercury at the conditions tested at Site 1.

Some of the other catalysts tested during the second long-term test period at Site 1 showed greater promise. Results for other catalyst materials are plotted in Figure 4. If the 2350-hr data for palladium on alumina and for IAC Carbon can be linearly extrapolated, it appears that these catalysts might have achieved a useful life in the range of 3000 to 4000 hours at the loading tested had the low temperature excursion not occurred. Note that the "time zero" oxidation used for these extrapolations was $100 \%$ rather than the screening test results for these two catalyst materials, since the screening tests were conducted at a much lower catalyst loading.

A comparison of the operating conditions for these catalyst beds to design conditions for flue gas $\mathrm{NO}_{\mathrm{X}}$ selective catalytic reduction (SCR) catalysts shows that it may not be practical to further increase the amount of catalysts in each bed as a means of extending bed life. This comparison is made in Table 9.

The data in Table 9 show that while the superficial velocity and space velocities through the field unit compare favorably to SCR conditions (i.e., indicate smaller reactor requirements), the area velocities do not. The area velocities for the second long-term test period are nearly two orders of magnitude lower than in the SCR units. The area velocities are calculated as the catalyst material's geometric (external) surface area divided by the flue gas flow rate. If we assume that mercury oxidation occurs primarily on the external surfaces of the catalyst materials (i.e., not in 


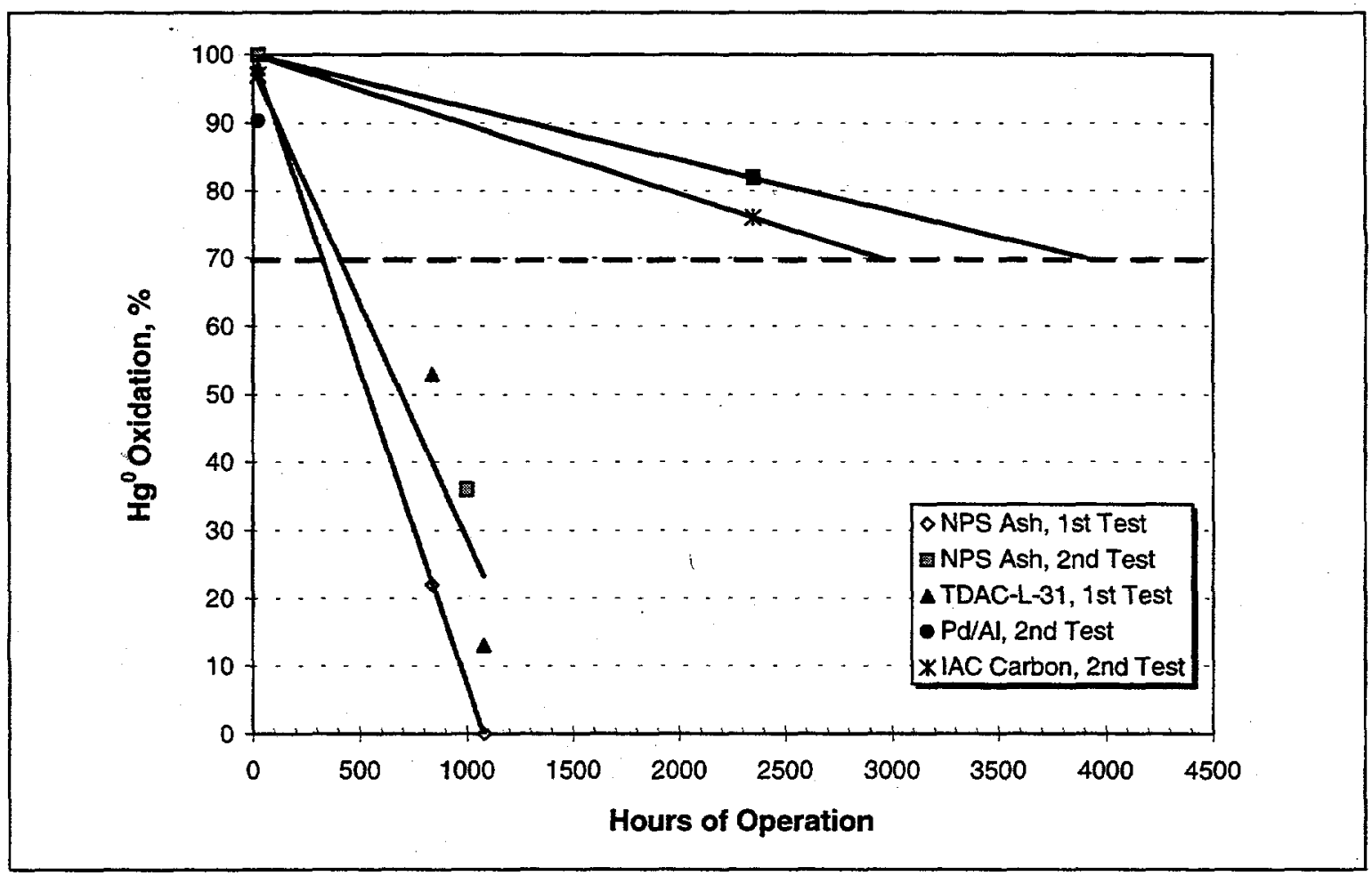

Figure 4. Site 1 Activity Results for Various Catalyst Materials

Table 9. Catalyst Characteristics for Two Mercury Catalyst Materials Compared to Characteristics of SCR Catalysts

\begin{tabular}{||l|c|c|c|}
\hline \multicolumn{1}{|c|}{ Catalyst Characteristic } & $\begin{array}{c}\text { FGD Carbon } \\
\text { (two beds) }\end{array}$ & $\begin{array}{c}\text { Palladium on } \\
\text { Alumina }\end{array}$ & $\begin{array}{c}\text { Range for SCR } \\
\text { Catalysts* }\end{array}$ \\
\hline $\begin{array}{l}\text { Superficial velocity through } \\
\text { catalyst bed, } \mathrm{ft} / \mathrm{sec}\end{array}$ & 18 & 18 & $5.4-12.5$ \\
\hline Space velocity, $\mathrm{hr}$ & $50,000^{-1}$ & $17,000^{* *}$ & $1700-10,300$ \\
\hline Area velocity, $\mathrm{ft} / \mathrm{hr}$ & $0.32^{* *}$ & $0.22^{* *}$ & $13-33$ \\
\hline
\end{tabular}

* Range reported for EPRI-funded pilot SCR installations at TVA Shawnee Station, NYSEG Kintigh Station, and Niagara-Mohawk Oswego Station.

** Based on the geometric volume and surface area of catalyst materials in test cells; ignores the volume and surface area of sand in each bed.

the pores), the area velocity probably represents the best parameter for scaling the sand bed reactor results to a commercially viable catalyst bed design. The area velocity comparison in Table 9 suggests that a much larger reactor than a typical SCR unit would be required for mercury oxidation, unless a much greater geometric surface area per unit volume of catalyst could be employed than in the honeycomb designs typically used in SCR. After making this comparison, it is apparent that future testing should focus on operating at lower catalyst loading. This might involve determining mechanisms for the loss of activity by the mercury oxidation 
catalysts, and attempting to extend catalyst life by avoiding deactivation rather than by testing at greater catalyst loading.

\section{Flue Gas Conditions at Site 1}

Table 10 summarizes the flue gas conditions at Site 1 measured at the beginning of the long-term test period in May 1998, and at the end in December. Results from measurements during Phase I are also included for comparison. The $\mathrm{SO}_{2}$ and $\mathrm{NO}_{\mathrm{X}}$ concentrations in the table are from the plant continuous emissions monitoring (CEM) system, while the remaining values are from manual method measurements by Radian.

\section{Table 10. Flue Gas Conditions During Site 1 Tests}

\begin{tabular}{|c|c|c|c|}
\hline Parameter & $\begin{array}{c}\text { Phase II - } \\
\text { December 1998 }\end{array}$ & $\begin{array}{c}\text { Phase II - May } \\
\mathbf{1 9 9 8}\end{array}$ & 1997 Phase I \\
\hline Inlet $\left(\mathrm{Hg}^{0}\right)^{*}$ & $21 \mu \mathrm{g} / \mathrm{Nm}^{3}$ & $4.2 \mu \mathrm{g} / \mathrm{Nm}^{3}$ & $10 \mu \mathrm{g} / \mathrm{Nm}^{3}$ \\
\hline Inlet $(\mathrm{Hg}$ total)* & $31 \mu \mathrm{g} / \mathrm{Nm}^{3}$ & $17 \mu \mathrm{g} / \mathrm{Nm}^{3}$ & $13 \mu \mathrm{g} / \mathrm{Nm}^{3}$ \\
\hline $\mathrm{Hg} \%$ oxidation & $33 \%$ & $76 \%$ & $22 \%$ \\
\hline Average $\mathrm{SO}_{2}$ & $1000 \mathrm{ppm}$ & $1500 \mathrm{ppm}$ & $1400 \mathrm{ppm}$ \\
\hline $\mathrm{SO}_{3}$ & - & $0.7 \mathrm{ppm}$ & - \\
\hline $\mathrm{HCl}$ & - & $1.8 \mathrm{ppm}$ & $1 \mathrm{ppm}$ \\
\hline Average $\mathrm{NO}_{\mathrm{X}}$ & $140 \mathrm{ppm}$ & $150 \mathrm{ppm}$ & $190 \mathrm{ppm}$ \\
\hline
\end{tabular}

*By Method 29T in May 1998, Ontario Hydro (KCl) method in December 1998. Phase I results are for the semicontinuous mercury analyzer.

Over this period of time, both the flue gas $\mathrm{SO}_{2}$ concentrations and flue gas mercury concentrations were observed to vary significantly. The plant reports that $\mathrm{SO}_{2}$ concentrations are known to vary with the lignite composition. However, these data provide the first indication that mercury levels in this lignite vary significantly as well. The coal mercury concentrations measured in May and December 1998 substantiate that this range of variability is due to changes in coal mercury content and not sampling and analytical variability; coal mercury content was observed to vary by almost a factor of two between the May and December samples. An attempt was made to close mass balances between the coal mercury and the mercury accounted for in the FGD inlet flue gas. These mass balance results are summarized in Table 11.

The mass balance closures of $130 \%$ and $167 \%$ are outside the desirable range $(100 \% \pm 20 \%)$ for trace metals measurement around a full-scale power plant. A closure of greater than $100 \%$ indicates that more mercury was accounted for in the flue gas at the FGD inlet and in the ESP ash than can be accounted for by the mercury in the coal fired. There appears to be two reasons why this closure is outside the desirable range. One is that the ash mercury content value used appears to be biased high. The material balance calculations use the results of one ESP ash analysis conducted on a sample collected in December; no comparable result was available from the May testing. This one analysis $(0.17 \mathrm{mg} / \mathrm{g})$ shows a much higher mercury concentration in the fly ash than expected; a value one order of magnitude lower would be expected based on measurements 
Table 11. Results of Mercury Mass Balances at Site 1

\begin{tabular}{|l|c|c|}
\hline \multicolumn{1}{|c|}{ Parameter } & May 1998 & December 1998 \\
\hline Coal mercury content, $\mathrm{mg} / \mathrm{kg}$ & 0.09 & 0.15 \\
\hline Amount of coal fired, tons/hr & 593 & 419 \\
\hline Mercury in coal fired, $\mathrm{b} / \mathrm{hr}$ & 0.11 & 0.13 \\
\hline $\begin{array}{l}\text { Total mercury concentration in ESP } \\
\text { outlet flue gas, } \mu \mathrm{g} / \mathrm{Nm}^{3}\end{array}$ & 17 & 31 \\
\hline Flue gas flow rate at ESP outlet, dscfm & & $1.8 \times 10^{6}$ \\
\hline Total mercury in flue gas, $\mathrm{b} / \mathrm{hr}$ & $1.9 \times 10^{6}$ & 0.20 \\
\hline Mercury concentration in fly ash, $\mathrm{mg} / \mathrm{kg}$ & 0.12 & 0.17 \\
\hline Fly ash collection rate, tons $/ \mathrm{hr}$ & $* *$ & 43 \\
\hline Mercury in fly ash collected, lb/hr & 75 & 0.01 \\
\hline Mercury in bottom ash, lb/hr & 0.02 & 0 (assumed) \\
\hline $\begin{array}{l}\text { Total mercury accounted for in flue gas } \\
\text { and fly ash, lb/hr }\end{array}$ & 0 (assumed) & 0.21 \\
\hline $\begin{array}{l}\text { Mercury material balance closure, \% of } \\
\text { coal mercury accounted for }\end{array}$ & 0.14 & 167 \\
\hline
\end{tabular}

*By combustion calculation.

**Not measured; assumed to be equal to December 1998 concentration.

at other sites and considering the volatility of mercury at flue gas temperatures. The May 1998 material balance would improve to an acceptable $109 \%$ closure if the ash mercury value were only $10 \%$ of the value used in the calculation shown. A sample of ash from the May 1998 testing will be analyzed to see if the actual value is, in fact, much lower.

For the December 1998 testing, even lowering the ash mercury content does not improve the material balance closure to within acceptable values. The revised average closure would be $157 \%$. The December values represent the averages from three individual sampling runs. A look at the run to run values shows that the Run 1 results are suspect. The Run 1 total mercury value for the FGD inlet was $36.4 \mu \mathrm{g} / \mathrm{Nm}^{3}$ while the other two runs showed considerably lower values of $26.8 \mu \mathrm{g} / \mathrm{Nm}^{3}$ and $28.7 \mu \mathrm{g} / \mathrm{Nm}^{3}$, respectively. Furthermore, the semi-continuous mercury analyzer did not indicate any values greater than $30 \mu \mathrm{g} / \mathrm{Nm}^{3}$ during this period. The coal mercury analysis for Run 1 showed a lower mercury concentration of $0.166 \mathrm{mg} / \mathrm{g}$ (dry sample basis), while the other two coal mercury analyses were $0.238 \mathrm{mg} / \mathrm{g}$ and $0.221 \mathrm{mg} / \mathrm{g}$.

When calculating the material balances for individual runs, the coal mercury recoveries for sampling Runs 2 and 3 were much better that for Run 1. Runs 2 and 3 showed recoveries of $131 \%$ and $144 \%$, whereas the observed recovery for Run 1 was over $200 \%$. The recoveries for Runs 2 and 3 would drop by about 10 percentage points if the ash mercury content proves to be too high, as expected. Thus, it appears that an ash mercury analysis bias affects both the May and December material balance closures, while the December average closure is adversely affected by sampling and/or analytical biases in the flue gas and coal analyses for the first sampling run. 
Measurements were also made at the FGD outlet each time. Past experience has shown that wet FGD systems effectively remove oxidized forms of mercury, but remove little if any elemental mercury. If this holds true, flue gas mercury measurements at the FGD system outlet provide an indication of the accuracy of the elemental mercury concentrations measured at the ESP outlet (FGD system inlet).

This comparison is made in Table 12, for the average of three runs each in May 1998 and December 1998. The results for May 1998 show the expected result, that elemental mercury concentrations at the FGD outlet location are similar to those measured at the inlet, and that $98 \%$ of the oxidized mercury appears to have been removed by the FGD system. The December 1998 results do not follow the expected trend. The FGD outlet elemental mercury concentration measured was $40 \%$ lower than the elemental mercury concentration measured at the inlet. It is doubtful that this much elemental mercury was removed across the FGD system. The apparent removal of oxidized mercury across the FGD system is high (94\%) as expected, though.

\section{Table 12. Comparison of FGD System Inlet and Outlet Elemental Mercury Concentrations}

\begin{tabular}{|c|c|c|c|c|c|}
\hline $\begin{array}{l}\text { Sampling } \\
\text { Method }\end{array}$ & $\begin{array}{c}\text { Sample } \\
\text { Location }\end{array}$ & $\begin{array}{c}\text { Elemental } \\
\text { Mercury } \\
\text { Concentration, } \\
\mu \mathrm{g} / \mathrm{Nm}^{3}\end{array}$ & $\begin{array}{c}\text { Oxidized } \\
\text { Mercury } \\
\text { Concentration, } \\
\mu \mathrm{g} / \mathrm{Nm}^{3} \\
\end{array}$ & $\begin{array}{c}\text { Total Mercury } \\
\text { Concentration, } \\
\mu \mathrm{g} / \mathrm{Nm}^{3}\end{array}$ & $\begin{array}{c}\text { Mercury } \\
\text { Oxidation } \\
\text { Percentag } \\
\quad \text { e } \\
\end{array}$ \\
\hline \multicolumn{6}{|c|}{ May 1998 Results } \\
\hline $\begin{array}{c}\text { Method } \\
29 \mathrm{~T}\end{array}$ & $\begin{array}{l}\text { FGD } \\
\text { inlet }\end{array}$ & 4.2 & 12.9 & 17.1 & 76 \\
\hline $\begin{array}{l}\text { Method } \\
29 \mathrm{~T}\end{array}$ & $\begin{array}{l}\text { FGD } \\
\text { outlet }\end{array}$ & 4.8 & 0.2 & 5.0 & 4 \\
\hline \multicolumn{6}{|c|}{ December 1998 Results } \\
\hline $\begin{array}{l}\text { Ontario } \\
\text { Hydro }\end{array}$ & $\begin{array}{l}\text { FGD } \\
\text { inlet }\end{array}$ & 20.6 & 10.1 & 30.6 & 33 \\
\hline $\begin{array}{l}\text { Ontario } \\
\text { Hydro }\end{array}$ & $\begin{array}{l}\text { FGD } \\
\text { outlet }\end{array}$ & 12.1 & 0.6 & 12.7 & 5 \\
\hline
\end{tabular}

The December results suggest that the FGD inlet (ESP outlet) elemental mercury concentration measurement is biased high. Once again, the results of the first run in December appear to skew the average. The first run showed an elemental mercury concentration of $25.9 \mu \mathrm{g} / \mathrm{Nm}^{3}$ at the inlet, but only $8.9 \mu \mathrm{g} / \mathrm{Nm}^{3}$ at the outlet of the FGD systems. The other runs showed better agreement. On the second run the inlet elemental $\mathrm{Hg}$ concentration was $16.8 \mu \mathrm{g} / \mathrm{Nm}^{3}$ and the outlet was almost the same at $16.5 \mu \mathrm{g} / \mathrm{Nm}^{3}$. The third run showed $19.0 \mu \mathrm{g} / \mathrm{Nm}^{3}$ at the inlet and $11.4 \mu \mathrm{g} / \mathrm{Nm}^{3}$. These comparisons suggest that, particularly for the first run, the elemental mercury concentrations measured at the ESP outlet (FGD inlet) in December 1998 were biased high. The reason for this apparent bias is not known. 
Over the course of the long-term tests at Site 1, the total mercury concentrations measured by the semi-continuous analyzer (not shown) varied over an even wider range than did the manual method measurements, from $4 \mu \mathrm{g} / \mathrm{Nm}^{3}$ to $36 \mu \mathrm{g} / \mathrm{Nm}^{3}$. Similarly, the elemental mercury concentrations varied from $<2$ to $18 \mu \mathrm{g} / \mathrm{Nm}^{3}$. The inlet mercury oxidation percentage indicated by the semi-continuous analyzer varied from $30 \%$ to $80 \%$.

The flue gas total mercury concentrations and mercury oxidation percentages measured with the EPRI semi-continuous mercury analyzer were compared to flue gas composition data measured with the plant's CEM system. The strongest correlations were between total mercury content and flue gas $\mathrm{SO}_{2}$ and $\mathrm{NO}_{\mathrm{X}}$ concentrations. The flue gas total mercury content was observed to be inversely related to flue gas $\mathrm{SO}_{2}$ concentration. This correlation is illustrated in Figure 5 . The $\mathrm{R}^{2}$ value for a linear least-squares fit of these data is 0.72 , indicating that these two parameters are likely related. The total mercury concentration data were observed to be directly related to flue gas $\mathrm{NO}_{\mathrm{X}}$ concentration. These data are plotted in Figure 6 . This is a weaker relationship than that with $\mathrm{SO}_{2}$, with an $\mathrm{R}^{2}$ value of 0.48 . The material balance calculations summarized in Table 11 indicate that a high percentage of the coal mercury is accounted for in the gas phase of the flue gas at the ESP outlet. Thus, variations in flue gas mercury content appear to be directly related to changes in lignite mercury content and not affected by the distribution of mercury between the flue gas, bottom ash, and fly ash. These relationships suggest that for Site 1 the fuel mercury content is lower in lignite with higher sulfur levels and higher in lignite with higher fuel nitrogen content. However, it would take considerably more data to make this observation conclusive.

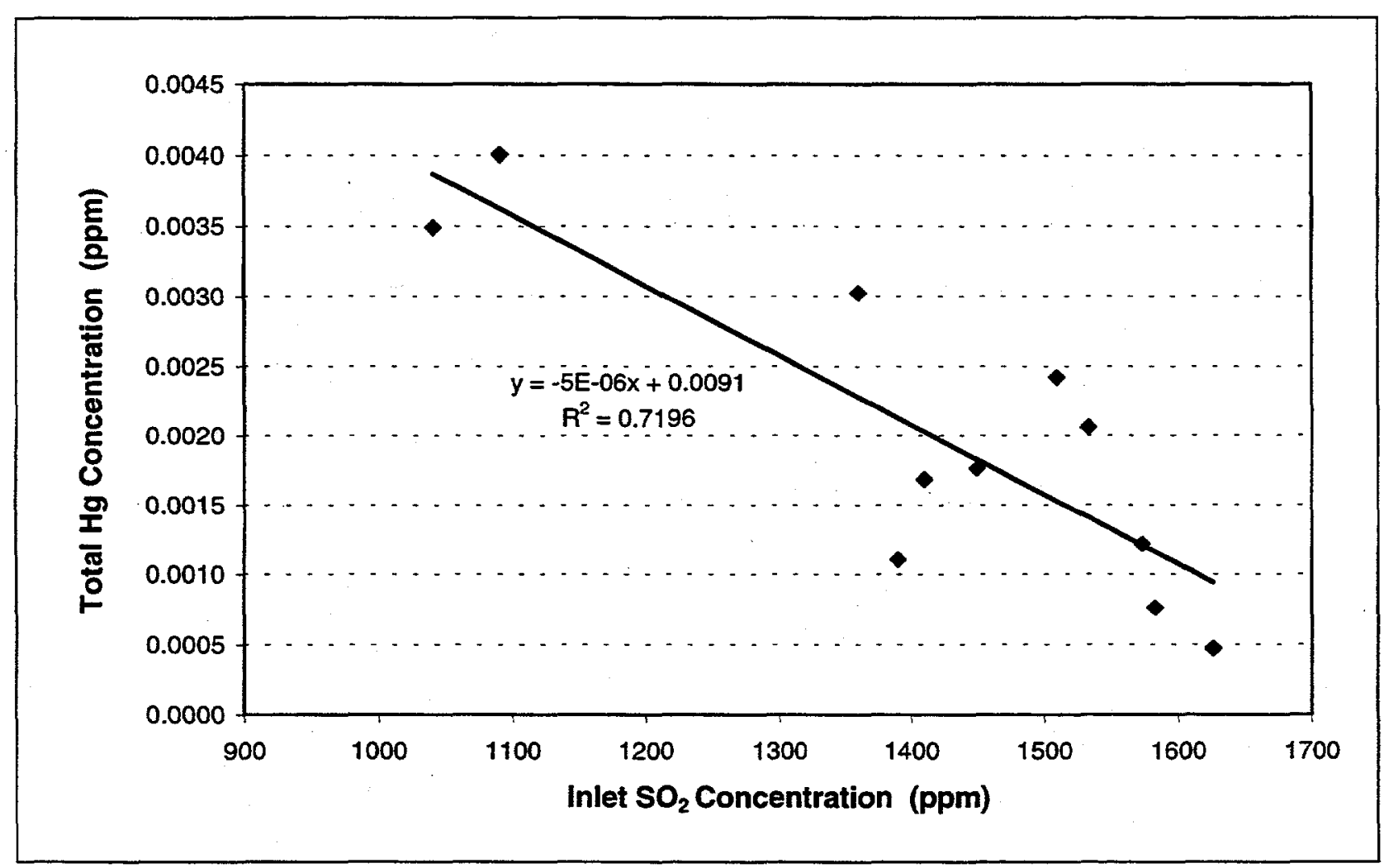

Figure 5. Total Mercury Concentration vs. FGD Inlet $\mathrm{SO}_{2}$ Concentration at Site 1 


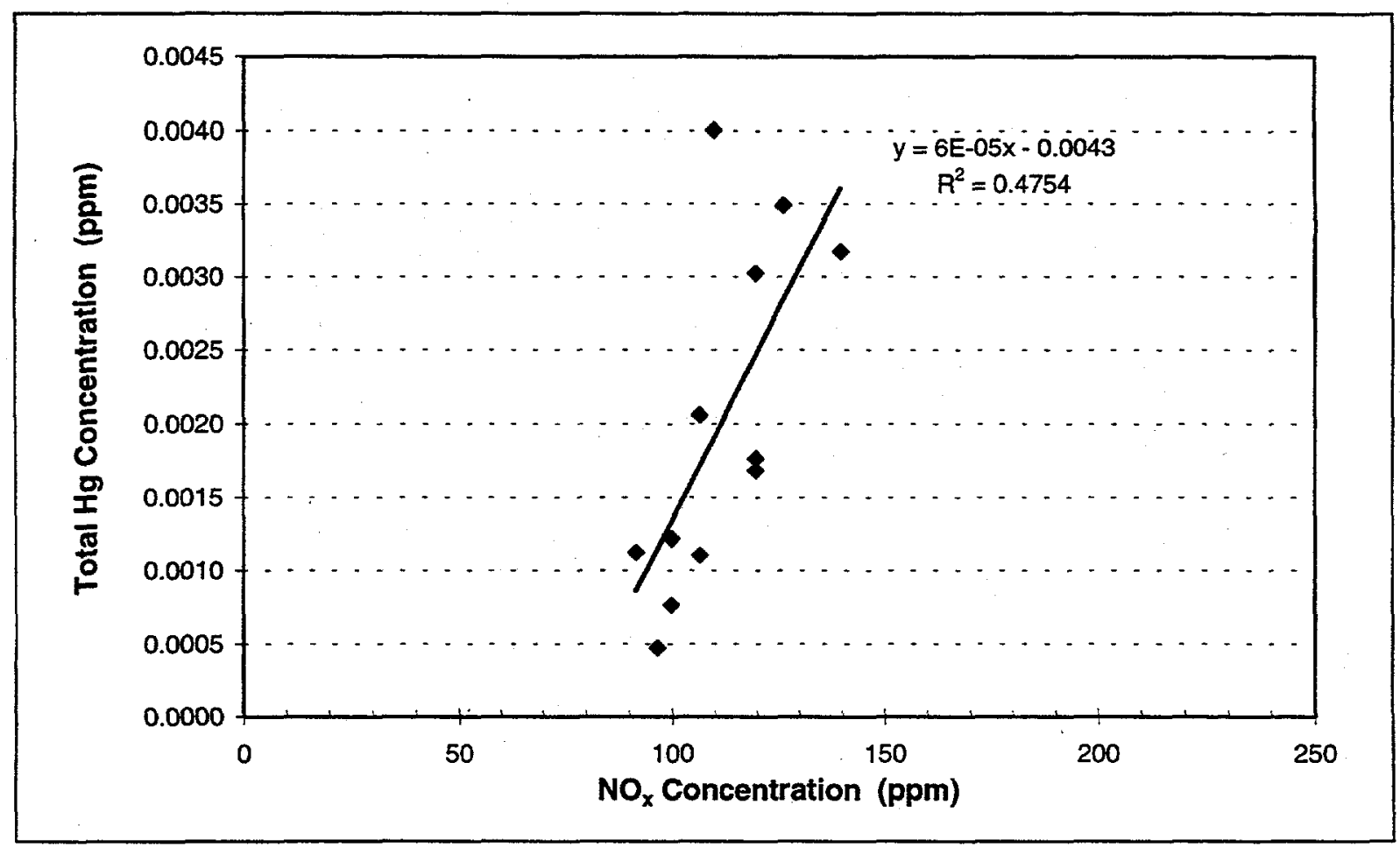

Figure 6. Total $\mathrm{Hg}$ Concentration vs. Flue Gas $\mathrm{NO}_{x}$ Concentration at Site 1

Other relationships were apparent, but the $\mathrm{R}^{2}$ values for linear least squares fit of the data suggest that the relationships are weak at best (i.e., $\mathrm{R}^{2}$ values of 0.3 or less). For example, mercury oxidation percentages appeared to increase with higher $\mathrm{SO}_{2}$ and $\mathrm{NO}_{\mathrm{X}}$ concentrations, as indicated in Figures 7 and 8, respectively. Other parameters showed no obvious relationship with total mercury concentrations or oxidation percentages. These included boiler load and flue gas $\mathrm{CO}_{2}$ concentrations (an indicator of excess air levels). These data plots are not included in the technical note.

Samples of coal and fly ash from Site 1 were analyzed for a wide range of species as well as mercury. The results of these analyses are summarized in Appendix A.

\section{Bench-Scale Catalyst Regeneration Test Results}

Bench-scale tests were also carried out to investigate the possibility of regenerating catalysts that were deactivated during flue gas treatment at Site 1 , and to attempt to elucidate the cause of the loss of activity after extended operation in the Site 1 flue gas. Regeneration tests have been completed on samples from the first long-term test group that were removed after 1100 hours of operation, but the samples recovered from the second long-term test period at Site 1 have not yet had regeneration tests conducted. However, a number of procedures have been conducted from both long-term test periods in an attempt to determine what species desorb from these materials on regeneration, and to elucidate the cause of the loss of activity after extended operation in the Site 1 flue gas. These results are also discussed in this section of the technical note. 


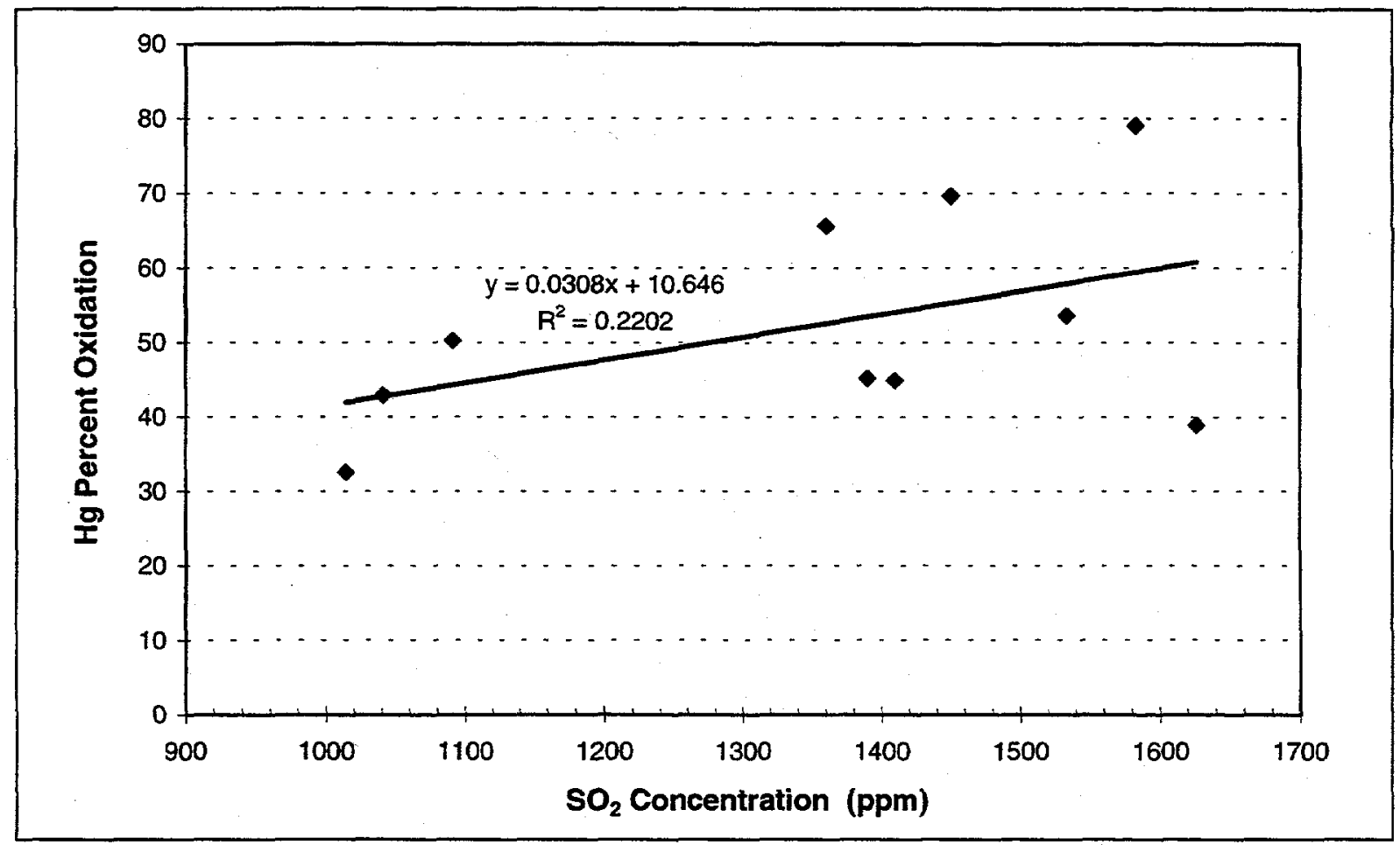

Figure 7. Percent Elemental Mercury Oxidation vs. FGD Inlet $\mathrm{SO}_{2}$ Concentration

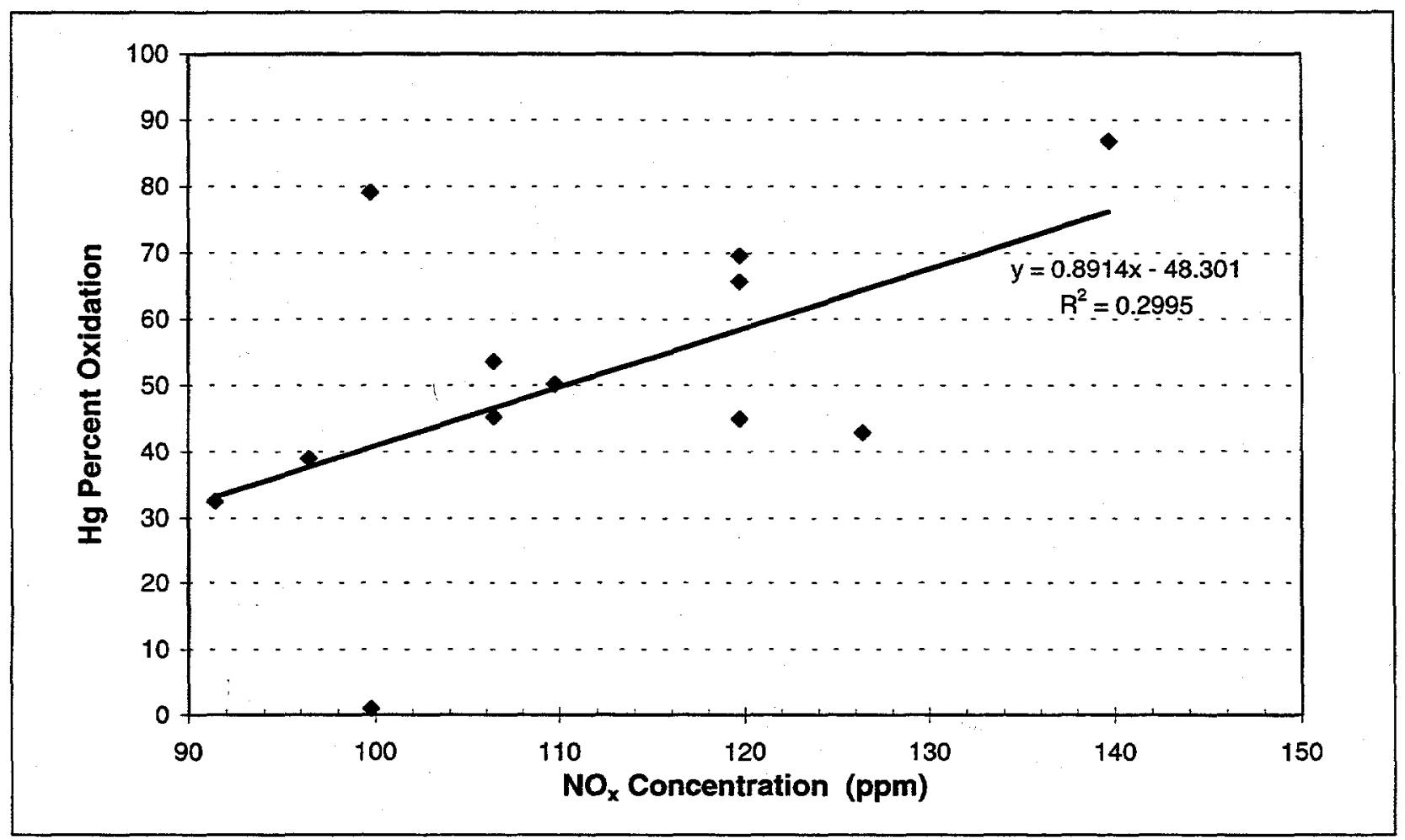

Figure 8. Percent Elemental Mercury Oxidation vs. Flue Gas $\mathrm{NO}_{\mathrm{x}}$ Concentration 


\section{Regeneration of Samples from the First Long-Term Test Period at Site 1}

First, the recovered catalyst samples were evaluated for mercury oxidation activity in laboratory oxidation tests with simulated flue gas. In these tests a portion $(5 \mathrm{~g})$ of the catalyst-sand mixture was fixed in a 0.5 -inch quartz tube and heated to $300^{\circ} \mathrm{F}$. A mercury-containing flue gas, simulating that of Site 1, was then reacted with the catalysts. The gas exiting the fixed beds was analyzed for mercury. Tests were run until total mercury breakthrough was achieved across the column, such that no further mercury adsorption was occurring. The mercury exiting the bed was then speciated to evaluate the ability of the previously spent catalyst material to oxidize elemental mercury. The results of these tests are summarized in Table 13. The last column of the table shows the corresponding mercury oxidation results for these catalyst samples at the end of the first long-term test period at Site 1.

\section{Table 13. Laboratory Results for Catalyst Materials Recovered from the Field Test Unit After 1100 Hours of Operation at Site 1}

\begin{tabular}{|l|c|c|c|c|}
\hline $\begin{array}{c}\text { Treated } \\
\text { Catalyst } \\
\text { Name }\end{array}$ & $\begin{array}{c}\text { Catalyst Mass } \\
\text { Reacted } \\
(\mathbf{m g})\end{array}$ & $\begin{array}{c}\text { Lab Mercury } \\
\text { Adsorption } \\
\text { Capacity }(\mu \mathrm{g} / \mathrm{g})\end{array}$ & $\begin{array}{c}\text { Lab Mercury } \\
\text { Oxidation } \\
(\%)\end{array}$ & $\begin{array}{c}\text { Site 1 Oxidation } \\
\text { after 1100 hrs } \\
(\%)\end{array}$ \\
\hline High LOI ash (1B) & 100 & 639 & 99 & 0 \\
\hline FGD carbon (2A) & 16.7 & $40^{*}$ & $0 *$ & 0 \\
\hline FGD carbon (2B) & 16.7 & 660 & 97 & 26 \\
\hline IPAC-5 (3A) & 16.7 & 1438 & 27 & 0 \\
\hline TDAC-L-31 (3B) & 16.7 & 396 & 95 & 13 \\
\hline Pyrex wool & 1000 & 4 & 0 & - \\
\hline Sand (1A) & 10000 & 0.16 & 0 & - \\
\hline
\end{tabular}

*Average of two test results.

The results in Table 13 indicate that several samples showed much greater reactivity toward mercury in the simulated flue gas than they had just prior to being recovered from the field test unit at Site 1. The downstream FGD carbon (location 2B in the field test unit) and tire carbon (TDAC-L-31) both showed mercury oxidation greater than $95 \%$, as did the high-LOI fly ash sample. Each of these samples also showed good mercury adsorption capacities. The upstream FGD carbon (position 2A) showed very little adsorption of mercury and no oxidation, indicating that it was indeed spent. The biomass (IPAC-5) carbon showed relatively low oxidation (27\%) despite a high adsorption capacity.

The apparent activity of the catalysts in the bench tests suggests that they were not permanently deactivated after 1100 hours of flue gas operation. It is not currently known what caused the differences in activity between the field and bench tests. It is likely that changes occurred at the catalyst surfaces (e.g., species desorbed) after being removed from the Site 1 flue gas. The lab results may indicate that something present in the Site 1 flue gas is able to affect the catalyst performance without permanently altering the catalyst surface. It is interesting that the three samples that showed high mercury oxidation in bench tests were all located in the second 
(downstream) fixed-beds in the catalyst test unit. This suggests that they may have been shielded from harmful species by the upstream beds. The adsorption of such species could explain why the carbons located in upstream beds (FGD location 2A and IPAC-5) appear to have been affected more permanently.

During the long-term field tests, it was apparent that selenium was adsorbed to the surfaces within the reaction vessel (the Site 1 flue gas is known to contain relatively high selenium levels). This was evident by a pink color in the removed sand and Pyrex wool packing. Benchscale adsorption/oxidation tests were carried out with samples of the "pink" sand and wool to evaluate their reactivity toward mercury; reagent sand and wool normally show no reactivity toward mercury. These results are also included in Table 13.

Although neither sample oxidized mercury in the simulated flue gas, both showed the ability to adsorb mercury. The treated Pyrex wool achieved over $90 \%$ mercury removal during the initial stages of the test, and a total adsorption capacity of $4 \mu \mathrm{g} / \mathrm{g}$. The sand showed a much lower mercury capacity of $0.16 \mu \mathrm{g} / \mathrm{g}$. Although this value is quite low, if similar adsorption on the sand occurred in the other Site 1 samples, the sand would have been responsible for a positive adsorption bias of approximately $60 \mu \mathrm{g} / \mathrm{g}$ in the carbon test results in Table 13.

These test results suggest that selenium and/or some other species has adsorbed on the sand and Pyrex wool and reacts with mercury. Another interesting observation was that selenium apparently desorbed from the catalyst surfaces during all of the bench-scale adsorption/oxidation tests with the materials recovered from Site 1 . This was evident by color changes in the flow lines as well as in some impinger solutions. These qualitative results indicate that the selenium may be easily removed from the catalysts.

Once the performance of the catalysts recovered from Site 1 in synthetic flue gas was determined, laboratory regeneration tests were conducted. These tests involved treating the spent catalysts with either $\mathrm{CO}_{2}$ or $\mathrm{N}_{2}$ gas at a given temperature for periods up to several hours. The ability of the treated catalysts to oxidize elemental mercury in simulated flue gas was then evaluated.

Regeneration tests began by placing $5 \mathrm{~g}$ of the Site-1-treated catalyst/sand mixtures in a temperature-controlled column. After warming the column to the desired temperature, tests were started by flowing $1 \mathrm{~L} / \mathrm{min}$ of a regeneration gas across the catalysts. The amount of mercury exiting each column was followed using the semi-continuous mercury analyzer. Each test was run until no mercury desorbed from the catalysts; test periods were generally 2 to 3 hours. Upon completing the regeneration tests, the temperature of each fixed-bed column was adjusted to $300^{\circ} \mathrm{F}$. Mercury adsorption/oxidation tests were then performed by reacting each bed with a synthetic flue gas that simulated Site 1 conditions. The amount of mercury adsorbed by the catalysts was monitored. Upon reaching adsorption equilibrium, the mercury oxidation across each catalyst bed was then measured.

Regeneration and oxidation tests were carried out with Site 1-treated FGD Carbon (upstream bed) and IPAC-5. Both were recovered after the first long-term test period and both proved inactive in the bench-scale, simulated flue gas oxidation tests described above. Regeneration and 
oxidation tests were also carried out with TDAC-L-31 which, although inactive when removed at Site 1 , showed a high level of activity ( $95 \%$ oxidation) in the subsequent lab tests with synthetic flue gas. The purpose of testing this catalyst was to ensure that the regeneration process did not have a detrimental effect on catalyst performance. All three samples were tested with $\mathrm{CO}_{2}$ as the regeneration gas; this gas was chosen because of its use in some carbon activation processes. IPAC-5 was also regenerated in nitrogen.

The results of the regeneration tests are compared in Table 14 to previous bench-scale and Site 1 results with these same catalysts. Improvements were obtained for each of the samples when treated at the higher regeneration temperatures $\left(700\right.$ to $\left.800^{\circ} \mathrm{F}\right)$. The two previously inactive catalysts (FGD Carbon and IPAC-5) oxidized over $90 \%$ of the elemental mercury after this regeneration. Regeneration tests performed with these two catalysts at the lower temperatures of $275^{\circ}$ and $400^{\circ} \mathrm{F}$ produced little improvement in catalytic oxidation. No significant difference was observed between nitrogen and carbon dioxide as the regeneration gas for IPAC-5.

Table 14. Results of Bench-Scale Catalyst Regeneration Tests

\begin{tabular}{|c|c|c|c|c|c|c|c|}
\hline $\begin{array}{c}\text { Sorbent } \\
\text { Name }\end{array}$ & $\begin{array}{c}\text { Regen- } \\
\text { eration } \\
\mathbf{G a s}\end{array}$ & $\begin{array}{c}\text { Regen- } \\
\text { eration } \\
\text { Temp. } \\
(\mathbf{F})\end{array}$ & $\begin{array}{c}\text { Desorbed } \\
\mathbf{H g} \\
(\mathbf{\mu g})\end{array}$ & $\begin{array}{c}\text { Re- } \\
\text { Adsorbed } \\
\mathbf{H g} \\
(\mathbf{\mu g})\end{array}$ & $\begin{array}{c}\mathbf{H g} \\
\text { Oxida- } \\
\text { tion } \\
(\%)\end{array}$ & $\begin{array}{c}\text { Pre- } \\
\text { regeneration } \\
\text { (Lab) } \\
\text { Oxidation (\%) }\end{array}$ & $\begin{array}{c}\text { Previous } \\
\text { Site 1 } \\
\text { Oxida-tion } \\
(\%)\end{array}$ \\
\hline $\begin{array}{c}\text { FGD } \\
\text { Carbon }\end{array}$ & $\mathrm{CO}_{2}$ & 275 & 10.75 & 5.82 & 22 & 0 & 0 \\
\hline $\begin{array}{c}\text { IAC } \\
\text { Carbon }\end{array}$ & $\mathrm{CO}_{2}$ & 800 & 17.84 & 7.92 & 93 & 0 & 0 \\
\hline $\begin{array}{c}\text { TDAC-L- } \\
31\end{array}$ & $\mathrm{CO}_{2}$ & 400 & 3.50 & 14.29 & 95 & 95 & 13 \\
\hline $\begin{array}{c}\text { TDAC-L- } \\
31\end{array}$ & $\mathrm{CO}_{2}$ & 700 & 6.22 & 19.27 & 98 & 95 & 13 \\
\hline IPAC-5 & $\mathrm{CO}_{2}$ & 400 & 4.61 & 0.99 & 37 & 27 & 0 \\
\hline IPAC-5 & $\mathrm{CO}_{2}$ & 700 & 6.70 & 20.25 & 91 & 27 & 0 \\
\hline IPAC-5 & $\mathrm{N}_{2}$ & 700 & 3.33 & 35.22 & 93 & 27 & 0 \\
\hline
\end{tabular}

As described above, mercury desorption occurred during each of the regeneration tests. The amount desorbed in the presence of $\mathrm{CO}_{2}$ increased as the temperature was increased to $700^{\circ} \mathrm{F}$ or $800^{\circ} \mathrm{F}$. The amount of mercury desorbed from IPAC -5 in the presence of nitrogen at $700^{\circ} \mathrm{F}$ was less than desorbed in $\mathrm{CO}_{2}$ at the same temperature.

Adsorption of mercury by each regenerated catalyst was measured in the subsequent oxidation tests, which were conducted with simulated Site 1 flue gas. The extent of adsorption was greater for samples regenerated at higher temperatures and was typically higher than the amount desorbed. This suggests that the regeneration process involves reactions at the surface that change or remove species other than just mercury. One observation during the regeneration tests was the presence of red deposits at some locations in the flow lines or impingers downstream of the fixed bed; it is believed that these deposits were rich in selenium. This indicates although selenium appeared to have enhanced mercury adsorption by the sand and Pyrex wool, selenium may also play a role as an inhibitor to catalytic mercury oxidation. 
The results of these regeneration tests were promising, and indicate that regeneration of the spent catalysts should be possible. It is not known, however, how the catalyst life of the regenerated materials will compare to that of the original, reagent materials over an extended period of operation in flue gas.

\section{Evaluation of Species Adsorbed on the Catalyst Materials Recovered from the Long-term Tests at Site 1}

The simulated flue gas used in the laboratory does not contain a number of trace species that are present in actual flue gas (e.g., selenium), and one or more these trace species may be responsible for catalyst deactivation. Laboratory tests were conducted on materials recovered from the second long-term test at Site 1 using simulated Site 1 gas to determine if the absence of trace species would affect performance. Performance tests were also conducted on fresh (reagent) catalyst materials at the same catalyst loading (catalyst concentration in sand) as used in the field samples. These fresh catalyst tests allow for direct comparison of results with the catalysts recovered from Site 1 . Results of the tests with both the fresh (reagent) and recovered catalyst materials are shown in Table 15 and Figure 9.

\section{Table 15. Capacity and Oxidation at Site 2 Simulated Conditions and $300^{\circ} \mathrm{F}$ for Reagent and Field Samples Recovered from the Second Long-Term Test}

\begin{tabular}{|c|c|c|c|c|c|c|c|}
\hline \multirow[b]{2}{*}{$\begin{array}{c}\text { Sample } \\
\text { Type }\end{array}$} & \multirow[b]{2}{*}{ Sample } & \multirow{2}{*}{$\begin{array}{c}\text { Sample } \\
\text { Loading } \\
\text { (mg Sample } \\
\text { / g Sand) }\end{array}$} & \multicolumn{2}{|c|}{$\begin{array}{c}\text { Hg Adsorption } \\
\text { Capacity } \\
\text { (mg Hg/g Sample) } \\
\end{array}$} & \multicolumn{3}{|c|}{$\begin{array}{c}\text { Elemental Hg Oxidation } \\
(\% \text { Inlet })\end{array}$} \\
\hline & & & Reagent & \begin{tabular}{|c|} 
Field \\
Sample in \\
Lab
\end{tabular} & Reagent & $\begin{array}{l}\text { Field } \\
\text { Sample } \\
\text { in Lab }\end{array}$ & \begin{tabular}{|c|} 
Field \\
Sample \\
at Site 1 \\
\end{tabular} \\
\hline Blank & Sand & 1000 & & 0 & & 0 & 0 \\
\hline \multirow[t]{3}{*}{ Carbon } & FGD-1 & 6.7 & 487 & 727 & 81 & 95 & $89^{* *}$ \\
\hline & FGD-2 & .6 .7 & 487 & 1295 & 81 & 97 & 0 \\
\hline & IAC carbon & 6.7 & 783 & 4576 & 97 & 98 & $76^{* *}$ \\
\hline Fly ash & NPS ash & 37.3 & 297 & $>2589^{*}$ & 32 & $\sim 65$ & 0 \\
\hline $\begin{array}{l}\text { Metal/ } \\
\text { catalyst }\end{array}$ & $\mathrm{Pd} /$ Alumina & 40 & 5 & 128 & 83 & 70 & 0 \\
\hline
\end{tabular}

* Estimated.

** These values are suspect because of an apparent measurement bias in the field at the end of the second long-term test at Site 1.

The results in Table 15 and Figure 9 show that the elemental mercury oxidation percentages for recovered field samples tend to equal or exceed those of the fresh reagents, and were generally much higher than measured in the field in December at Site 1. As discussed previously, similar effects were seen in the materials recovered from the first long-term test period at Site 1. Although the samples were either partially or completely spent at the end of Site 1 long-term pilot tests, oxidation performance appears to be restored in a similar gas without the trace 


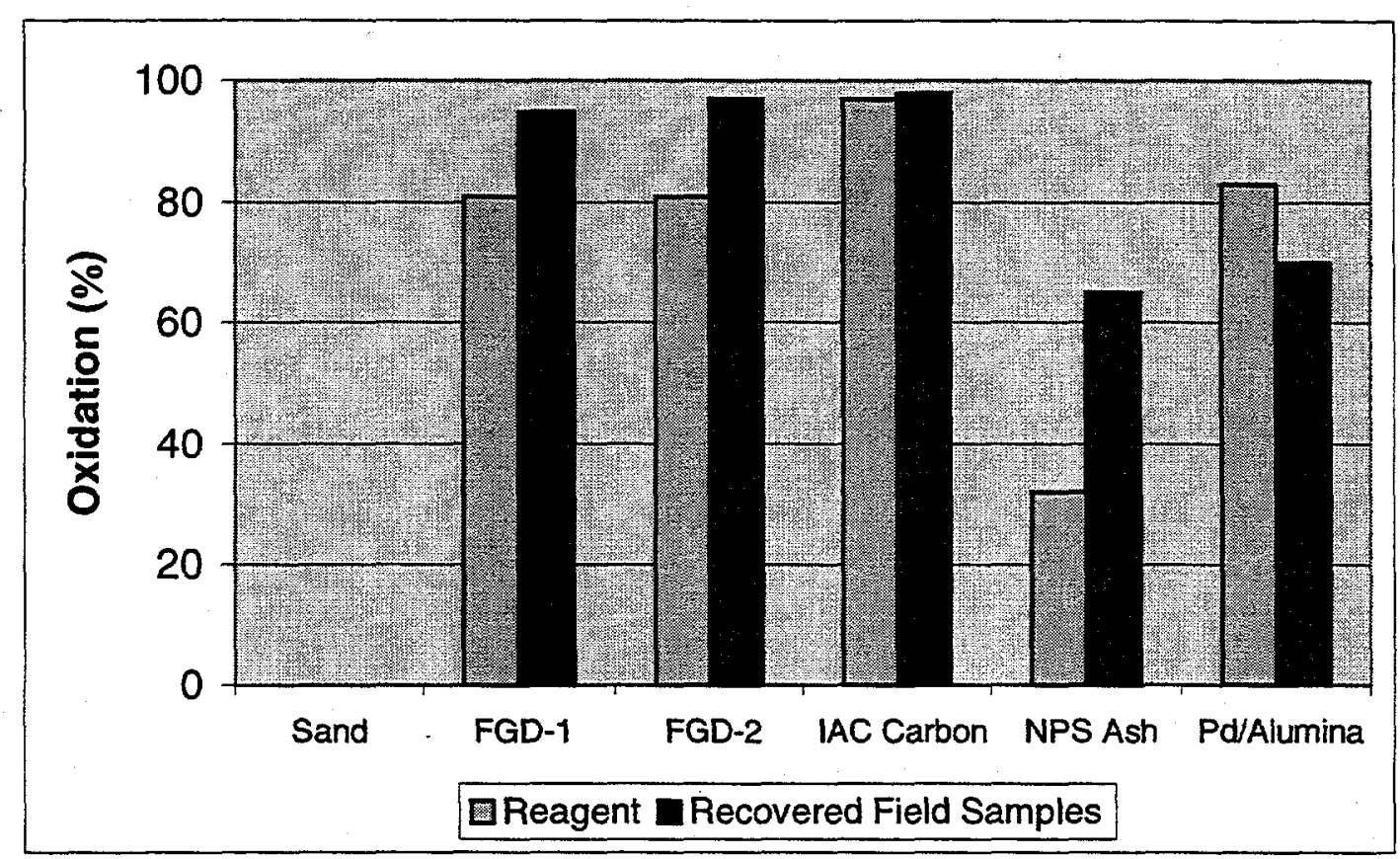

\section{Figure 9. Comparison of Elemental Mercury Oxidation between Reagents and Recovered Field Samples at Site 1 Conditions and $300^{\circ} \mathrm{F}$}

components. Note that the performance measured for the fresh FGD carbon material was lower than has previously been measured at simulated Site 1 conditions $(\sim 95 \%)$.

Laboratory tests were performed in an attempt to elucidate the mechanisms involved in the catalyst deactivation in actual flue gas. The adsorption or formation of sulfuric acid at the catalyst surface may be a poisoning effect that leads to inhibiting mercury oxidation activity. Previous testing by Radian has shown that some mercury sorbent materials are capable of adsorbing $\mathrm{SO}_{2}$ from simulated flue gases. This often leads to substantial decreases in the surface $\mathrm{pH}$, most likely due to the formation of sulfuric acid through oxidation reactions at the catalyst surface. It is also possible that $\mathrm{SO}_{3}$ in the flue gas adsorbs directly onto the catalyst surfaces.

Acid leaching tests were performed to determine the amount of acid species removed from flue gas-treated catalysts when they were allowed to equilibrate in water. This test was performed with samples from both the first and second long-term catalyst test at Site 1 and with fresh reagent mixtures. In these tests, a known mass of catalyst/sand sample was added to a fixed volume of water and the slurry was stirred for over 30 minutes. The $\mathrm{pH}$ of the equilibrated solutions was measured and used to calculate an acid concentration at the catalyst surface. It was assumed that the acid leached was $\mathrm{H}_{2} \mathrm{SO}_{4}$ present on catalyst surfaces, and that this $\mathrm{H}_{2} \mathrm{SO}_{4}$ content represented $\mathrm{SO}_{2}$ adsorbed from the flue gas.

Table 16 summarizes the $\mathrm{pH}$ measurements and the calculations of $\mathrm{SO}_{2}$ adsorbed by each catalyst material. Since the catalyst materials were mixed with sand, the amount of $\mathrm{SO}_{2}$ adsorbed on the Site 1 sand blank was subtracted from the total amount of $\mathrm{SO}_{2}$ adsorbed on each catalyst/sand 
Table 16. Determination of $\mathrm{SO}_{2}$ Adsorbed on Site 1 Long-Term Catalysts

\begin{tabular}{|c|c|c|c|c|c|c|}
\hline \multirow[b]{2}{*}{ Sorbent } & \multirow{2}{*}{$\begin{array}{c}\text { Catalyst } \\
\text { Loading in } \\
\text { Sand } \\
(\mathrm{mg} / \mathrm{g})\end{array}$} & \multicolumn{2}{|c|}{ pH } & \multirow{2}{*}{$\begin{array}{c}\mu \text { moles } \mathrm{SO}_{2} \\
\text { Adsorbed on } \\
\text { Catalyst/Sand } \\
\text { Mixture } \\
\end{array}$} & \multirow{2}{*}{$\begin{array}{c}\mu \mathrm{g} \mathrm{SO}_{2} \\
\text { Adsorbed } \\
\text { on } \\
\text { Catalyst }\end{array}$} & \multirow{2}{*}{$\begin{array}{c}\mathrm{SO}_{2} \\
\text { Adsorbed/g } \\
\text { Catalyst } \\
\text { (mg/g) }\end{array}$} \\
\hline & & Reagent & $\begin{array}{c}\text { Recovered } \\
\text { Catalyst }\end{array}$ & & & \\
\hline \multicolumn{7}{|c|}{ Materials Recovered from the First Long-Term Test at Site 1} \\
\hline Sand & 1000 & 5.23 & \begin{tabular}{|l|l|}
3.68 & \\
\end{tabular} & \begin{tabular}{|c|c|}
3.0 & \\
\end{tabular} & - & -- \\
\hline $\begin{array}{l}\text { FGD carbon, bed } \\
\# 1\end{array}$ & 3.33 & 6.58 & 3.35 & 6.7 & 234 & 70.2 \\
\hline $\begin{array}{l}\text { FGD carbon, bed } \\
\# 2\end{array}$ & 3.33 & -- & 3.12 & 11.4 & 533 & 160.1 \\
\hline TDAC-L-31 & 3.33 & 6.36 & 3.72 & 2.9 & -12 & -3.7 \\
\hline High LOI ash & 20 & 6.74 & 2.98 & 15.7 & 810 & 40.5 \\
\hline IPAC-5 & 3.33 & 5.85 & 3.33 & 7.0 & 253 & 75.9 \\
\hline \multicolumn{7}{|c|}{ Materials Recovered from the Second Long-Term Test at Site 1} \\
\hline Sand & 1000 & 5.23 & 3.67 & \begin{tabular}{|l|}
3.1 \\
\end{tabular} & -- & -- \\
\hline $\begin{array}{l}\text { FGD carbon, bed } \\
\# 1\end{array}$ & 33.3 & 8.31 & 2.56 & 41.3 & 2444 & 73.4 \\
\hline $\begin{array}{l}\text { FGD carbon, bed } \\
\# 2\end{array}$ & 33.3 & -- & 2.45 & 53.2 & 3207 & 96.3 \\
\hline Pd/Alumina & 200 & 4.34 & 4.05 & 0.7 & -158 & -0.8 \\
\hline IAC carbon & 33.3 & 5.75 & 2.43 & 55.7 & 3365 & 101.1 \\
\hline High LOI ash & 200 & 8.44 & 2.27 & 80.6 & 4956 & 24.8 \\
\hline
\end{tabular}

mixture to "back calculate" the amount of $\mathrm{SO}_{2}$ adsorbed on the catalyst material itself. Table 16 indicates the loading for each catalyst per gram of sand.

Figure 10 compares the $\mathrm{SO}_{2}$ adsorption by the different catalyst materials (after the sand blank results were subtracted). The results indicated that with the exception of TDAC-L-31, the carbon samples adsorbed the highest levels of $\mathrm{SO}_{2}$ during both long-term tests. The tire-based TDAC-L31 carbon showed no $\mathrm{SO}_{2}$ adsorption when that due to sand was taken into account. This suggests that the surface of the tire carbon differs from the other carbons such that $\mathrm{SO}_{2}$ adsorption is inhibited. This did not translate into better mercury oxidation activity, however. The high LOI fly ash showed lower $\mathrm{SO}_{2}$ pickup than most of the carbons. The palladium/alumina sample showed no apparent $\mathrm{SO}_{2}$ adsorption, as the catalyst/sand mixture showed less $\mathrm{SO}_{2}$ adsorption than the Site 1 sand blank. These results may be significant since the second Site 1 long-term results indicated good long-term reactivity for both of these samples.

It is interesting that for FGD carbon more $\mathrm{SO}_{2}$ adsorption occurred in the second fixed-bed than in the first. Field results indicated that the first bed was more quickly deactivated (for mercury oxidation) than the second. These results suggest that a gas species other than $\mathrm{SO}_{2}$ may dominate 


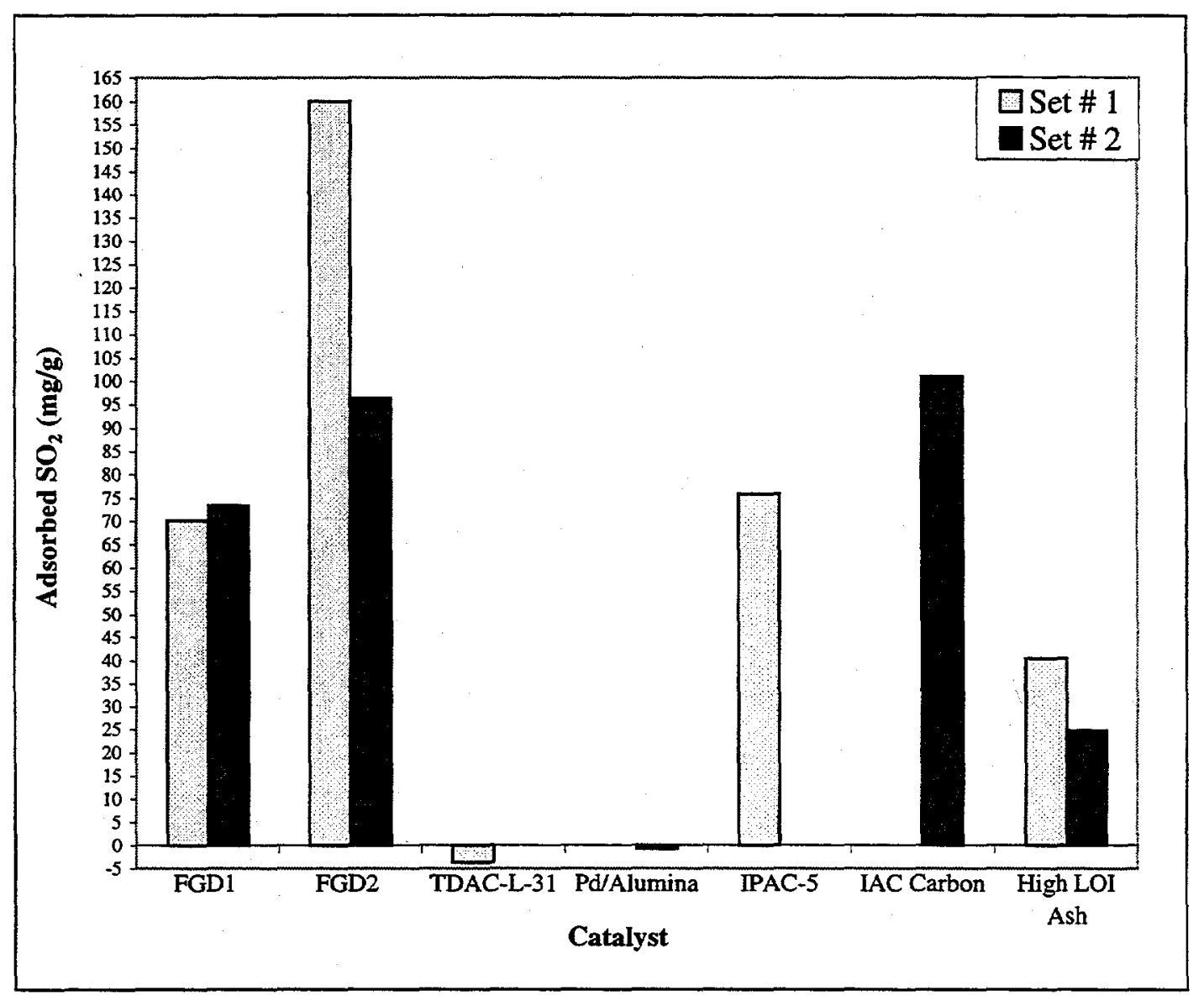

Figure 10. Results of Acid Leaching Tests on Catalyst Samples from the First and Second Long-Term Tests at Site 1

the catalyst deactivation. It is possible that such a species is adsorbed in the first fixed bed, subsequently making surface sites unavailable for adsorption of $\mathrm{SO}_{2}$ which then passes on to the second bed.

Additional characterization of the recovered Site 1 samples was performed to determine what species desorb, and in what quantities, in a further attempt to elucidate deactivation mechanisms. Two approaches were taken to quantifying these parameters. One was to analyze the composition of fresh reagents, recovered field samples, and regenerated field samples. Species adsorbed during field testing were determined by the difference between reagent and recovered field sample concentrations of the species analyzed, and species desorbed during regeneration were determined by the difference between recovered field sample and regenerated sample concentrations.

The other approach was to scrub and analyze the regeneration (desorption) off-gas. The desorption tests were conducted using a $1 \mathrm{~L} / \min \mathrm{CO}_{2}$ purge at $700^{\circ} \mathrm{F}$. The desorbed species were determined by passing the effluent gas through impingers containing $10 \%$ hydrogen peroxide 


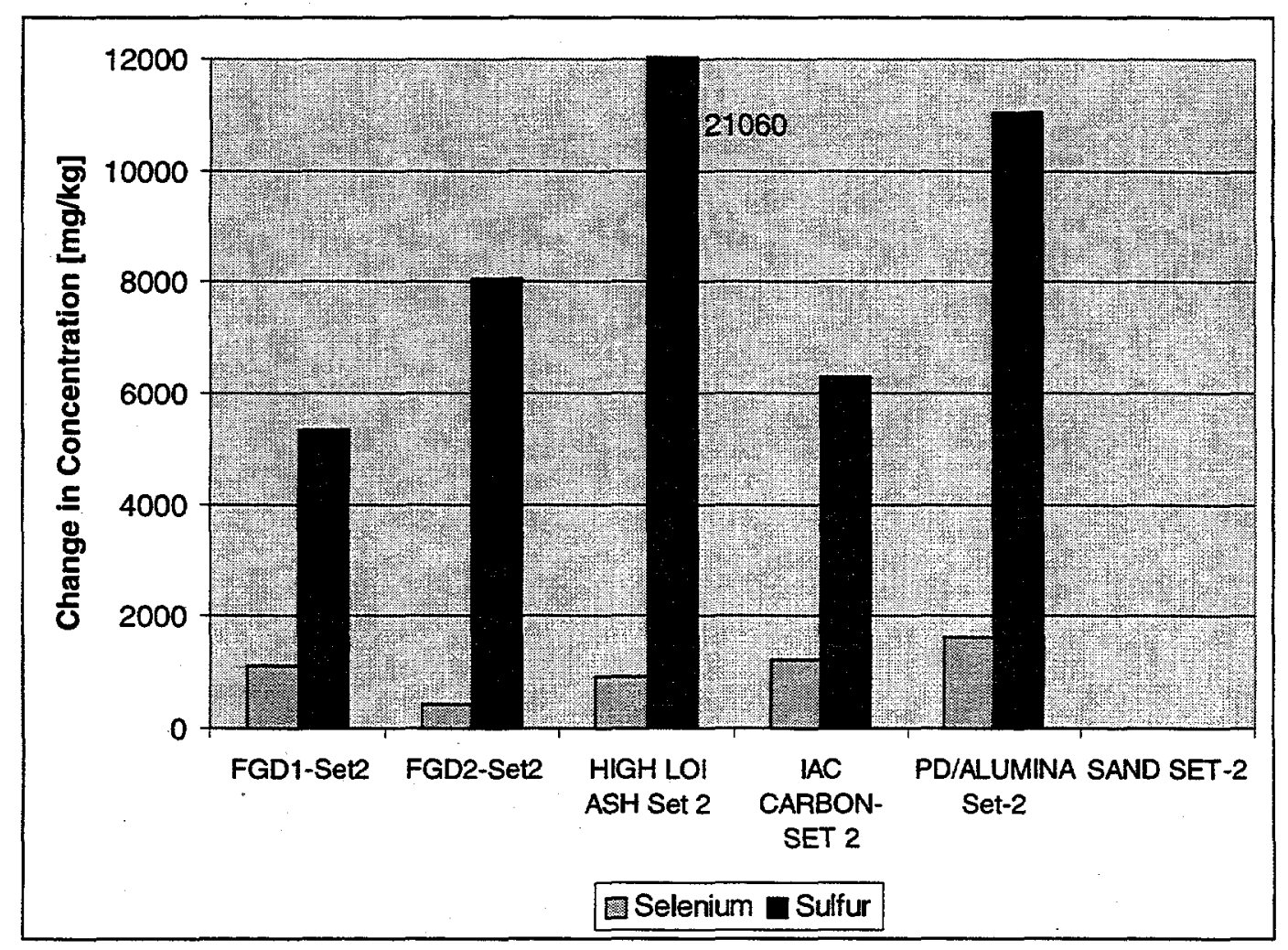

Figure 11. Measured Increases in Selenium and Sulfur Concentrations During Field Testing at Site 1 (Samples from Second Long-Term Test)

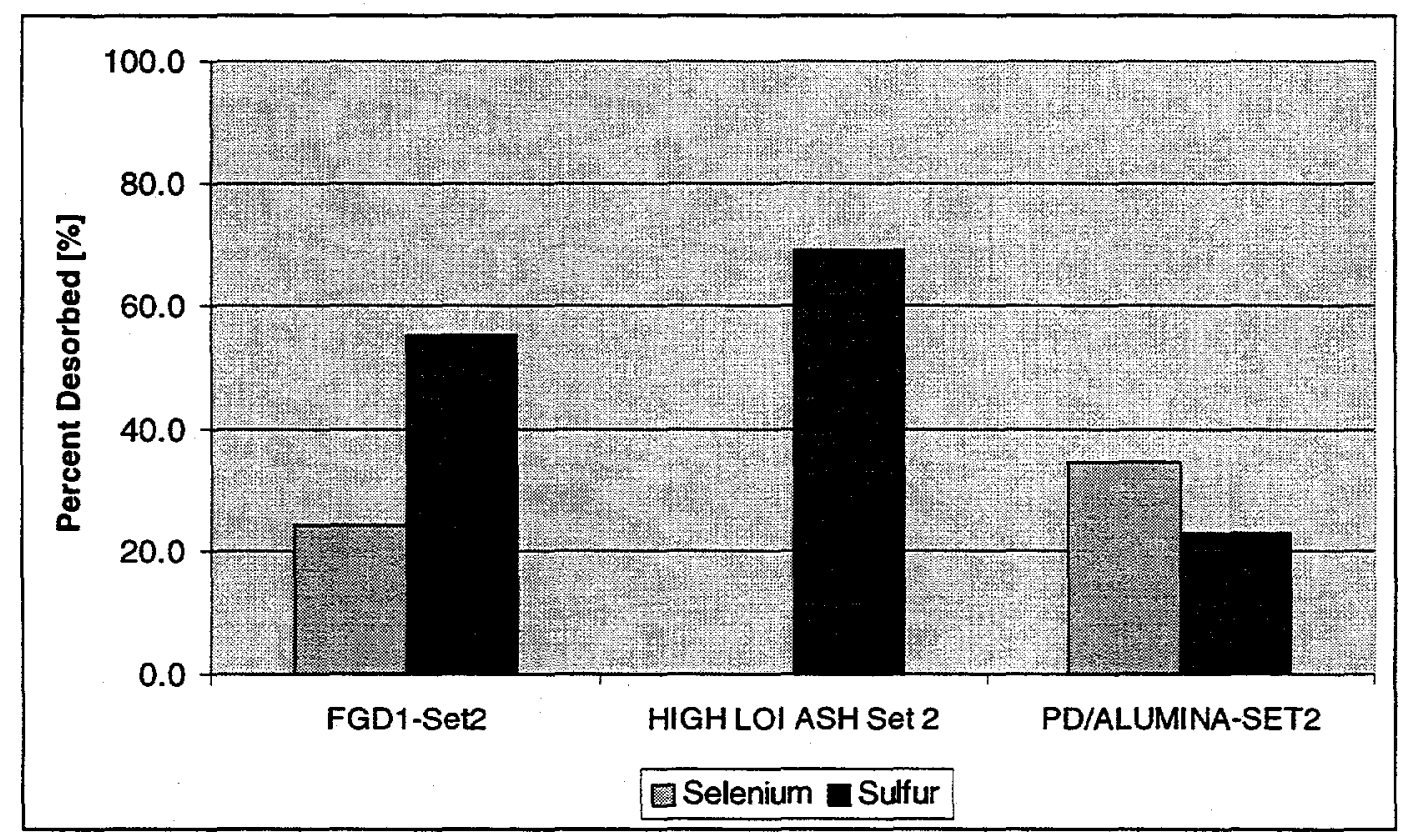

Figure 12. Percent of Adsorbed Material that Desorbed during Regeneration with $\mathrm{CO}_{2}$ at $700^{\circ} \mathrm{F}$ (Samples from Second Long-Term Test) 
$\left(\mathrm{H}_{2} \mathrm{O}_{2}\right)$ and $5 \%$ nitric acid $\left(\mathrm{HNO}_{3}\right)$ with subsequent analysis of the impingers by the protocol described in EPA Method 29.

Examination of the catalyst bulk chemistry results confirms earlier hypotheses that selenium and sulfur (as $\mathrm{SO}_{2}$ and/or $\mathrm{SO}_{3}$ ) are the primary species that adsorbed from the Site 1 flue gas. A summary of the concentration changes for both of these species during the long-term testing at Site 1 is presented in Figure 11, and the percent of adsorbed sulfur and selenium which desorbed during subsequent regeneration is shown in Figure 12.

In Figure 11, comparison of the upstream (FGD-1) and downstream (FGD-2) field samples of FGD Carbon shows that 50\% more sulfur species adsorbed in the second FGD bed while $150 \%$ more selenium adsorbed in the first bed. The sulfur results qualitatively confirm the relative acid leaching results presented in Table 15 for these two samples. However, the High LOI Ash showed higher sulfur adsorption quantities than either of the FGD samples in Figure 11, but had indicated significantly lower sulfur adsorption in the acid leaching test results presented in Table 15 .

Figure 12 shows the percentages of sulfur and selenium desorbed from each catalyst based on chemical analyses of field samples and laboratory regenerated material. The FGD-1 sample showed more efficient desorption of sulfur than of selenium while the Pd/Alumina catalyst showed the opposite result. Test results for the High LOI Ash sample indicated a higher percentage desorption of sulfur than that from the other two sample types. However, the High LOI Ash sample analyses also show higher selenium concentrations in the regenerated sample than in the field sample from Site 1 . Since this does not seem to be physically possible, it raises some concern over the accuracy of the results.

This unexpected result was seen for several trace species. The solid samples tested in these experiments were analyzed using two different digestion methods to improve the accuracy for different trace metals present. However, the tests still show higher concentrations of some species in the regenerated samples than in the field samples, which does not seem physically possible. It is likely that these results indicate a measurement bias. Analysis of aluminum concentrations in the catalysts proved to be particularly difficult, especially for the $\mathrm{Pd} / \mathrm{Alumina}$ catalyst. The accuracy of these trace species analyses could possibly be improved by using a "customized" baseline matrix as a method blank for each individual analysis; a common matrix was used for all of the samples analyzed. However, this approach would add significantly to the cost of conducting these analyses, and it did not seem that improving the accuracy of these trace element analyses would provide enough new information to justify the added expense.

No results are presented for the analyses of the regeneration gas impingers. The impinger analyses in general showed poor recovery of sulfur and selenium compared to the desorbing amounts indicated by bulk catalyst sample analyses. Also, concentrations of other species in the impinger solutions were not appreciably greater than "blank" analyses for the same species, which indicates no measurable desorption and capture of species other than selenium and sulfur. This also does not agree with the bulk catalyst chemical analyses. It appears that either these impingers did not efficiently absorb the desorbing species in the regeneration gas or analytical 
problems existed. For these reasons, the impinger solution results are not considered to provide any useful information, and only the bulk catalyst chemical analyses results have been presented.

To date, recovered field samples have been tested for post-field performance in simulation gas, acid leaching as an indicator of $\mathrm{SO}_{2}$ adsorption; and bulk concentration changes. These results have shown that sulfur oxides and selenium had adsorbed on the catalysts recovered from Site 1 and desorb upon regeneration. Results were inconclusive about other trace species. To date, only selenium has been identified as a trace species adsorbed on spent catalysts that desorbs upon regeneration. Although the sulfur oxides behave in the same manner, $\mathrm{SO}_{2}$ is present in the simulation gas and should not affect catalyst activity in the laboratory compared to field results. Thus, selenium remains the leading candidate for being an adsorbed species in the spent catalysts that is not present in the simulation gas. Desorption of selenium in the laboratory runs could explain the high adsorption capacity and oxidation activity of the previously spent catalyst materials, but this mechanism has not been confirmed. Analysis of the desorption gas from spent catalysts from Site 1 tested in the laboratory at simulated Site 1 FGD inlet conditions may provide additional information.

Additional catalyst regeneration testing is also planned. The additional testing will determine the effectiveness of flue gas as a regeneration gas, and will determine the minimum amount of exposure time to hot regeneration gas to restore activity. While the initial regeneration tests used only the material recovered from Site 1 in July, subsequent testing will also study the materials recovered in December.

\section{ACKNOWLEDGEMENTS}

This research is being sponsored by the U.S. Department of Energy's Federal Energy Technology Center (Pittsburgh). We would like to thank DOE Project Manager Tom Brown for his support in this effort. We would also like to thank co-funder EPRI and their Project Manager for this effort, Dick Rhudy, for their support and for allowing us to procure the catalyst test unit being used on this project. Finally, we would like to thank the Site 1 utility for allowing us to test at their power plant and for the support they provided.

\section{REFERENCES}

1. Carey, T.R.; Hargrove, O.W., Jr.; Seeger, D.M.; Richardson, C.F.; Rhudy, R.G.; Meserole, F.B. Presented at the AIChE Spring National Meeting, Session 47, New Orleans, LA, February 25-29, 1996. 


\section{APPENDIX A}

Detailed Measurement Results from the Second Long-Term Test Period 
Table A-1. Site 1 Catalyst Performance After 1000 Hours of Operation

\begin{tabular}{|c|c|c|c||}
\hline $\begin{array}{c}\text { Catalyst } \\
\text { Name }\end{array}$ & $\begin{array}{c}\text { Test Unit } \\
\text { Position }\end{array}$ & $\begin{array}{c}\text { Catalyst } \\
\text { Loading } \\
(\mathbf{g})\end{array}$ & $\begin{array}{c}\mathbf{H g}^{\mathbf{0}} \\
\text { Oxidized } \\
(\mathbf{\%})\end{array}$ \\
\hline Sand blank & 2A & 75 & 7 \\
NPS high LOI ash & 2B & 14 & 36 \\
FGD carbon & 1A & 2.5 & 66 \\
FGD carbon & 1B & 2.5 & 81 \\
Pd/Alumina & 3A & 15 & $*$ \\
IAC carbon & 3B & 2.5 & $*$ \\
\hline
\end{tabular}

*1000-hr results not obtained due to analytical problem.

Table A-2. Site 1 Catalyst Performance during October Testing (2300-2400 Hours Total)

\begin{tabular}{|c|c|c|c|c|c|}
\hline $\begin{array}{c}\text { Catalyst } \\
\text { Name }\end{array}$ & $\begin{array}{c}\text { Test Unit } \\
\text { Position }\end{array}$ & $\begin{array}{c}\text { Total Hg } \\
\left(\boldsymbol{\mu} \mathbf{g} / \mathbf{N m}^{3}\right)\end{array}$ & $\begin{array}{c}\text { Elemental Hg } \\
\left(\boldsymbol{\mu g} / \mathbf{N m}^{\mathbf{3}}\right)\end{array}$ & $\begin{array}{c}\text { Elemental } \\
\mathbf{H g} \text { Oxidized } \\
(\%)\end{array}$ & $\begin{array}{c}\text { Total Gas } \\
\text { Exposure } \\
\left(\mathbf{m}^{3}\right)\end{array}$ \\
\hline Sand (day 1) & 2A & - & 7.3 & 12.4 & $415^{*}$ \\
\hline Sand (day 2) & 2A & 26.2 & 8.5 & 9.1 & $415^{*}$ \\
\hline $\begin{array}{c}\text { NPS high LOI } \\
\text { ash }\end{array}$ & 2B & 6.0 & 1.3 & 81.6 & 415 \\
\hline FGD carbon & 1A & 20.5 & 4.0 & 44.8 & 418 \\
\hline $\begin{array}{c}\text { FGD carbon } \\
\text { (day 1) }\end{array}$ & 1B & - & 4.24 & 41.7 & 418 \\
\hline $\begin{array}{c}\text { FGD carbon } \\
\text { (day 2) }\end{array}$ & 1B & 23.2 & 3.8 & 59.1 & 418 \\
\hline Pd/Alumina & 3A & $\geq 21.1^{* *}$ & 1.68 & 81.9 & 411 \\
\hline IAC carbon & 3B & 21.1 & 2.2 & 76.0 & 411 \\
\hline
\end{tabular}

* Total flow estimated based on manual measurements at flow settings; transducer for gas path \#2 not functioning properly.

** Total mercury not measured; is assumed to be $\geq 21.1$ since that amount is present in effluent of downstream column. 
Table A-3. Site 1 Catalyst Performance during November Testing (3027-3055 Total Hours)

\begin{tabular}{|c|c|c|c|c|c||}
\hline $\begin{array}{c}\text { Catalyst } \\
\text { Name }\end{array}$ & $\begin{array}{c}\text { Test Unit } \\
\text { Position }\end{array}$ & $\begin{array}{c}\text { Total Hg } \\
\left(\boldsymbol{\mu g} / \mathbf{N m}^{\mathbf{3}}\right)\end{array}$ & $\begin{array}{c}\text { Elemental } \\
\mathbf{H g} \\
\left(\boldsymbol{\mu g} / \mathbf{N m}^{\mathbf{3}}\right)\end{array}$ & $\begin{array}{c}\text { Elemental } \\
\mathbf{H g} \text { Oxidized } \\
(\boldsymbol{\%})\end{array}$ & $\begin{array}{c}\text { Total Gas } \\
\text { Exposure } \\
\left(\mathbf{m}^{\mathbf{3}}\right)\end{array}$ \\
\hline Sand (day 2) & 2A & 34.5 & 13.7 & 23.2 & $456^{*}$ \\
\hline NPS high LOI ash & 2B & 23.7 & 3.7 & 73 & $456^{*}$ \\
\hline FGD carbon & 1A & $\leq 35.9^{* *}$ & - & - & 484 \\
\hline FGD carbon & 1B & $\leq 35.9^{* *}$ & 20.2 & 0 & 484 \\
\hline Pd/Alumina & 3A & $\leq 35.9^{* *}$ & 18.1 & 0 & 428 \\
\hline IAC carbon & 3B & $\leq 35.9^{* *}$ & 19.1 & 0 & 428 \\
\hline
\end{tabular}

* Total flow estimated based on manual measurements at flow settings; transducer for gas path \#2 not functioning properly.

** Total mercury not measured; is assumed to be $\leq 35.9$ since that amount is present in the inlet.

\section{Table A-4. Site 1 Catalyst Performance during December Testing (3477-3488 total hours)}

\begin{tabular}{|c|c|c|c|c|c||}
\hline $\begin{array}{c}\text { Catalyst } \\
\text { Name }\end{array}$ & $\begin{array}{c}\text { Test } \\
\text { Unit } \\
\text { Position }\end{array}$ & $\begin{array}{c}\text { Total } \mathbf{H g} \\
\left(\boldsymbol{\mu g} / \mathbf{N m}^{\mathbf{3}}\right)\end{array}$ & $\begin{array}{c}\text { Elemental } \\
\mathbf{H g} \\
\left(\boldsymbol{\mu g} / \mathbf{N m}^{3}\right)\end{array}$ & $\begin{array}{c}\text { Elemental } \\
\text { Hg Oxidized } \\
(\boldsymbol{\%})\end{array}$ & $\begin{array}{c}\text { Total Gas } \\
\text { Exposure } \\
\left(\mathbf{N m}^{\mathbf{3}}\right)\end{array}$ \\
\hline Sand & 2A & 28.2 & 3.98 & 0 & $612^{*}$ \\
\hline NPS high LOI ash & 2B & 36.7 & 4.95 & 0 & $612^{*}$ \\
\hline FGD carbon & 1A & 30.2 & 0.45 & 88.6 & 622 \\
\hline FGD carbon & 1B & $\leq 30.2^{* *}$ & 4.61 & 0 & 622 \\
\hline Pd/Alumina & 3A & $\leq 27.0^{* * *}$ & 4.2 & 0 & 602 \\
\hline IAC carbon & 3B & $\leq 27.0^{* * *}$ & 0.94 & 76.1 & 602 \\
\hline
\end{tabular}

* Total flow estimated based on manual measurements at flow settings; transducer for gas path \#2 was not functioning properly.

** Total mercury not measured; is assumed to be $\leq 30.2 \mathrm{ug} / \mathrm{Nm}^{3}$ since that amount is present at sample port $1 \mathrm{a}$.

*** Total mercury not measured; is assumed to be $\leq 27.0 \mathrm{ug} / \mathrm{Nm}^{3}$ since that amount was present in the inlet and total breakthrough was measured across these catalysts during previous testing.

Italicized numbers indicate that the values are suspected to be erroneous. 